\title{
TIME-TEMPERATURE-TRANSFORMATION (TTT) DIAGRAMS FOR THE SLUDGE BATCH 3 - FRIT 418 GLASS SYSTEM
}

\author{
A.L. Billings \\ T.B. Edwards
}

March 2009

Environmental \& Chemical Process Technology Research Programs

Savannah River National Laboratory Aiken, SC 29808

This document was prepared in conjunction with work accomplished under Contract No. DE-AC09-08SR22470 with the U.S. Department of Energy.

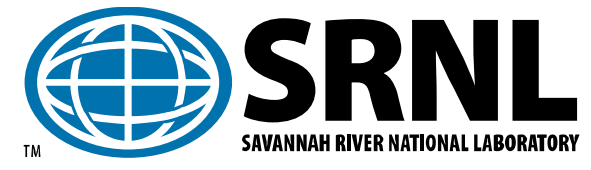


SRNL-STI-2009-00025

Revision 0

\section{DISCLAIMER}

This work was prepared under an agreement with and funded by the U.S. Government. Neither the U.S. Government or its employees, nor any of its contractors, subcontractors or their employees, makes any express or implied: 1. warranty or assumes any legal liability for the accuracy, completeness, or for the use or results of such use of any information, product, or process disclosed; or 2. representation that such use or results of such use would not infringe privately owned rights; or 3. endorsement or recommendation of any specifically identified commercial product, process, or service. Any views and opinions of authors expressed in this work do not necessarily state or reflect those of the United States Government, or its contractors, or subcontractors.

This document was prepared in conjunction with work accomplished under Contract No. DE-AC09-08SR22470 with the U.S. Department of Energy. 
Keywords: TTT, high-level waste glasses, DWPF, waste acceptance

Retention: permanent

\title{
TIME-TEMPERATURE-TRANSFORMATION (TTT) DIAGRAMS FOR THE SLUDGE BATCH 3 - FRIT 418 GLASS SYSTEM
}

\author{
A.L. Billings \\ T.B. Edwards
}

March 2009

Environmental \& Chemical Process Technology Research Programs

Savannah River National Laboratory

Aiken, SC 29808

This document was prepared in conjunction with work accomplished under Contract No. DE-AC09-08SR22470 with the U.S. Department of Energy. 


\section{REVIEWS AND APPROVALS}

\section{AUTHORS:}

A. L. Billings, Process Engineering Technology

Date

T. B. Edwards, Statistical Consulting Section

Date

\section{TECHNICAL REVIEWERS:}

K. M. Fox, Process Engineering Technology

Date

D. K. Peeler, Process Engineering Technology

Date

\section{APPROVERS:}

C. C. Herman, Manager, Process Engineering Technology

Date

S. L. Marra, Manager,

Date

Environmental \& Chemical Process Technology Research Programs

J.E. Occhipinti, Manager, Waste Solidification Engineering

Date 


\section{EXECUTIVE SUMMARY}

As a part of the Waste Acceptance Product Specifications (WAPS) for Vitrified High-Level Waste Forms defined by the Department of Energy - Office of Environmental Management, the phase stability must be determined for each of the projected high-level waste (HLW) types at the Savannah River Site (SRS). Specifically, WAPS 1.4.1 requires the glass transition temperature $\left(\mathrm{T}_{\mathrm{g}}\right)$ to be defined and time-temperature-transformation (TTT) diagrams to be developed. The $\mathrm{T}_{\mathrm{g}}$ of a glass is an indicator of the approximate temperature where the supercooled liquid converts to a solid on cooling or conversely, where the solid begins to behave as a viscoelastic solid on heating. A TTT diagram identifies the crystalline phases that can form as a function of time and temperature for a given waste type or more specifically, the borosilicate glass waste form. In order to assess durability, the Product Consistency Test (PCT) was used and the durability results compared to the Environmental Assessment (EA) glass.

The measurement of glass transition temperature and the development of TTT diagrams have already been performed for the seven Defense Waste Processing Facility (DWPF) projected compositions as defined in the Waste Form Compliance Plan (WCP). These measurements were performed before DWPF start-up and the results were incorporated in Volume 7 of the Waste Form Qualification Report (WQR). Additional information exists for other projected compositions, but overall these compositions did not consider some of the processing scenarios now envisioned for DWPF to accelerate throughput.

Changes in DWPF processing strategy have required this WAPS specification to be revisited to ensure that the resulting phases have been bounded. Frit 418 was primarily used to process HLW Sludge Batch 3 (SB3) at 38\% waste loading (WL) through the DWPF. The Savannah River National Laboratory (SRNL) fabricated a cache of glass from reagent grade oxides to simulate the SB3-Frit 418 system at a $38 \mathrm{wt} \% \mathrm{WL}$ for glass transition temperature measurement and TTT diagram development. The glass transition temperature $\left(\mathrm{T}_{\mathrm{g}}\right)$ was measured using differential scanning calorimetry (DSC) and was recorded to be $443 \pm 3{ }^{\circ} \mathrm{C}$.

Using the previous TTT diagrams as guidance, subsamples of the glass were isothermally heat treated for 0.5 to 768 hours at temperatures between $400{ }^{\circ} \mathrm{C}$ to $1100{ }^{\circ} \mathrm{C}$. Each of the 56 heat treated samples, along with quenched and centerline canister cooled (CCC) treated samples, were analyzed using Xray diffraction (XRD) and the PCT. Crystallization was detected only in samples treated at $600{ }^{\circ} \mathrm{C}$ for more than 192 hours, and 700,800 , and $900{ }^{\circ} \mathrm{C}$ for more than 48 hours. Phases crystallized were similar in composition if not the same as those found in the previous TTT studies. Six different crystalline phases were detected, including nepheline, acmite, lithium silicate, trevorite, krinovite, and albite. Overall, phases were spinel (iron) based, lithium metasilicate, sodium aluminosilicate or sodium transition metal silicate in composition. No new crystalline families were detected. Durability, as measured by the PCT, decreased when lithium silicate or nepheline crystals were present. Only one heat treated sample had a measured PCT response exceeding the benchmark EA glass, which was a sample treated at $600{ }^{\circ} \mathrm{C}$ for 768 hours. During normal processing at the DWPF these conditions would be highly unlikely to occur, even in an extreme accident scenario.

In order to continue to meet the requirements of the WCP, a simplified strategy is suggested for the generation of future TTT diagrams. A strategy has been developed that would require completing two more TTT diagrams for two averaged, future, predicted waste types. By creating diagrams for the resulting glass compositions of encompassing waste types, it will give insight to the crystallization regions possible for those averages. As discussed in the report, "Initial MAR Assessments to Access the Impact of Al-Dissolution on DWPF Operating Windows" (WSRC-STI- 
2007-00688), the majority of waste compositions could be grouped into two future flowsheet scenarios, with and without Al-dissolution. Compositions Cluster 2 and Cluster 4 represent these waste projections. MAR assessments were completed on the two clusters and possible frits and windows of operation were selected for each projected waste type. It is recommended that a TTT diagram be developed for the following:

- Cluster 2 combined with Frit-510 at a 34 wt \% WL

- Cluster 4 combined with Frit-418 at a 38 wt \% WL

Given the results of the current study showed little change in the types of crystalline phases formed after heat treatment as compared to the TTT diagrams for the WCP glasses, it is unlikely that extreme differences will occur in the TTT diagram for future waste forms, as long as extreme waste stream changes or new frit components are not introduced. 


\section{TABLE OF CONTENTS}

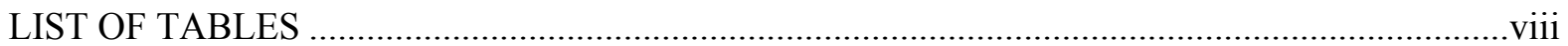

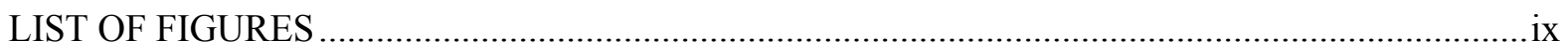

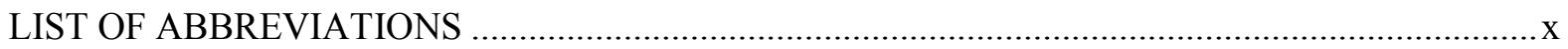

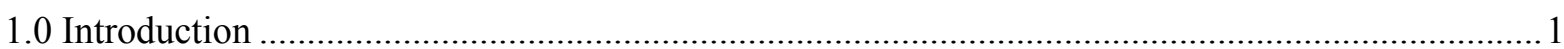

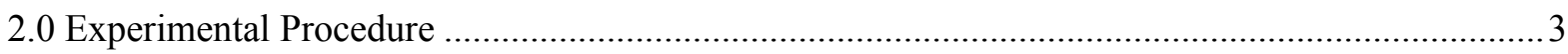

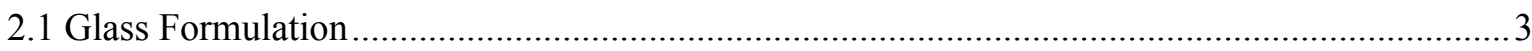

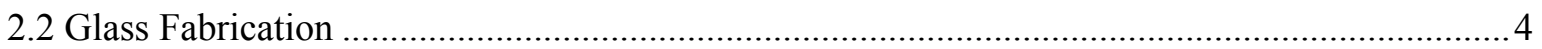

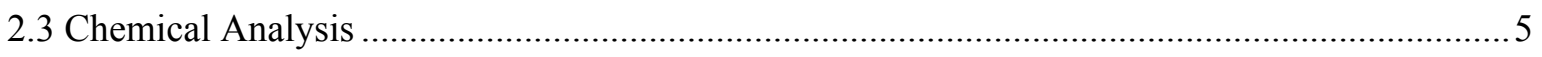

2.4 Glass Transition Temperature Determination.......................................................................... 5

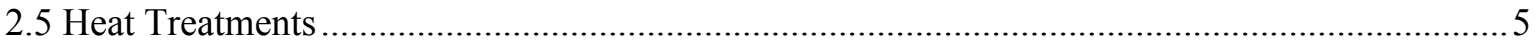

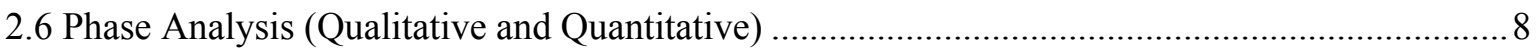

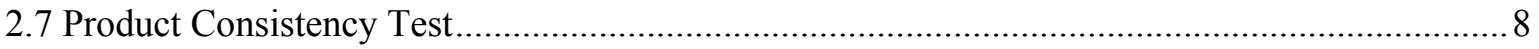

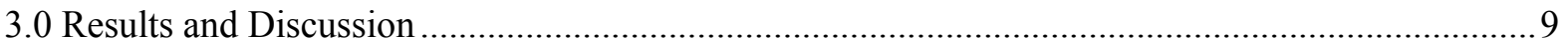

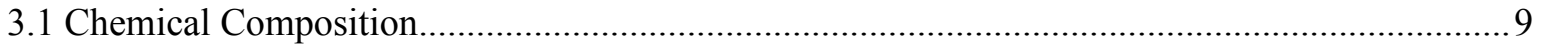

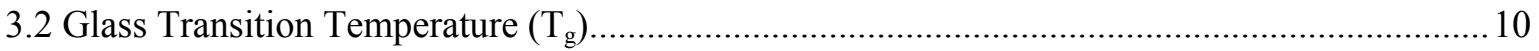

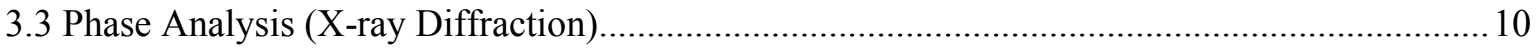

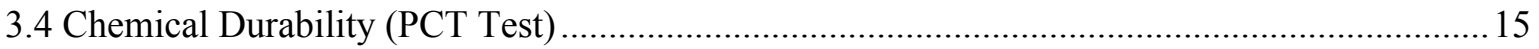

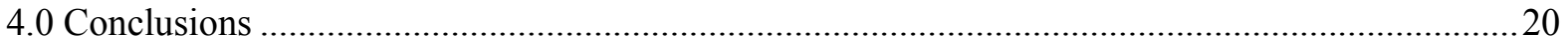

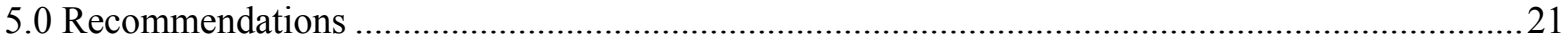

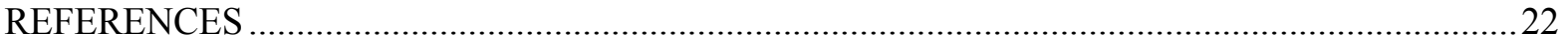

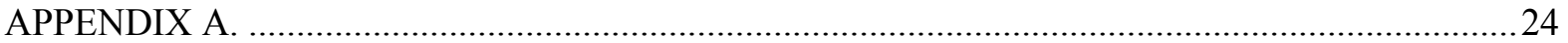




\section{LIST OF TABLES}

Table 1. Waste Form Compositions of the Seven WCP Glasses, ${ }^{2,3}$ and the SB3-Frit 418 Glass*....... 2

Table 2. Composition of the SB3 Nominal Sludge, Frit 418, Glass Composition at $38 \mathrm{wt} \% \mathrm{WL}$ and

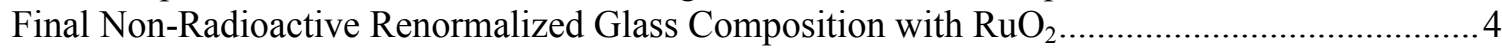

Table 3. Sample Identification, Treatment Times and Temperatures................................................ 7

Table 4. Target and Overall Measured Concentrations by Weight Percent Oxide for the Cache of

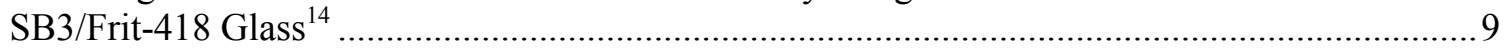

Table 5. Crystalline Phases of the Heat Treated Sample Detected With X-ray Diffraction................ 12

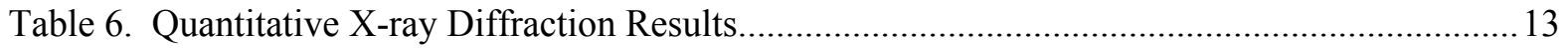

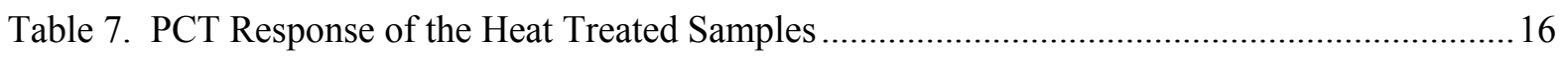

Table 8. PCT Response of the Heat Treated Samples and Crystal Phases Formed............................ 17

Table A1. Waste Form Compositions of Various Glasses Used to Generate TTT Diagrams...........24

Table A2. Frit Compositions Used to Calculate the Waste Glass Compositions in Table A1........25 


\section{LIST OF FIGURES}

Figure 1. The DSC curve and glass transition temperature determination by slope intercept method.

$\mathrm{T}_{\mathrm{g}}$ was determined to occur at $443 \pm 3{ }^{\circ} \mathrm{C}$ at a $20 \mathrm{~K} / \mathrm{min}$ heating rate...................................... 10

Figure 2. Time-Temperature-Transformation Diagram for SB3/Frit-418 Glass ............................... 14

Figure 3. Normalized B Release as a Function of Temperature and Duration of Heat Treatment...... 18

Figure 4. Normalized Li Release as a Function of Temperature and Duration of Heat Treatment..... 18

Figure 5. Normalized Na Release as a Function of Temperature and Duration of Heat Treatment.... 19

Figure 6. Normalized Si Release as a Function of Temperature and Duration of Heat Treatment.....19 


\section{LIST OF ABBREVIATIONS}

$\begin{array}{ll}\text { ARM } & \text { Approved Reference Material } \\ \text { bc } & \text { Bias-corrected } \\ \text { CCC } & \text { Centerline canister cooling } \\ \text { DOE } & \text { Department of Energy } \\ \text { DSC } & \text { Differential Scanning Calorimetry } \\ \text { DWPF } & \text { Defense Waste Processing Facility } \\ \text { EA } & \text { Environmental Assessment } \\ \text { HLW } & \text { High-Level Waste } \\ \text { ICP-AES } & \text { Inductively Coupled Plasma - Atomic Emission Spectroscopy } \\ \text { PCT } & \text { Product Consistency Test } \\ \text { PSAL } & \text { Process Science Analytical Laboratory } \\ \text { SB3 } & \text { Sludge Batch 3 } \\ \text { SRNL } & \text { Savannah River National Laboratory } \\ \text { SRS } & \text { Savannah River Site } \\ T_{g} & \text { Glass Transition Temperature } \\ T_{L} & \text { Liquidus Temperature } \\ \text { TTT } & \text { Time-Temperature-Transformation } \\ \text { WAPS } & \text { Waste Acceptance Product Specifications } \\ \text { WCP } & \text { Waste Form Compliance Plan } \\ \text { WL } & \text { Waste Loading } \\ \text { WQR } & \text { Waste Form Qualification Report } \\ \text { XRD } & \text { X-ray Diffraction }\end{array}$




\subsection{INTRODUCTION}

The Defense Waste Processing Facility (DWPF) is currently immobilizing high-level liquid waste by combining sludge (or waste) with frit (a prefabricated glass), melting the slurry mix of sludge and frit and pouring the molten glass into stainless steel canisters to create the final waste form at the Savannah River Site (SRS). Eventually, these canistered waste forms will be sent to the Civilian Radioactive Waste Management System (repository) for final disposal. In order to assure acceptance by the repository, the Department of Energy (DOE) has defined requirements which DWPF canistered waste forms must meet. These requirements are the Waste Acceptance Product Specifications (WAPS). ${ }^{1}$ WAPS 1.4.1 requires the measurement of glass transition temperature and the development of time-temperature-transformation (TTT) diagrams for the projected glass compositions to be processed through the facility. Prior to radioactive operations, glass transition temperatures and TTT diagrams were completed for seven projected compositions (known as the Waste Form Compliance Plan glasses) originally anticipated to compositionally bound the DWPF glass waste forms. ${ }^{2}$ Since that time, higher waste loadings, less sludge washing, and different tank blending scenarios and salt processing strategies have been implemented. In addition, frit development strategies have significantly changed, resulting in higher alkali glass systems being processed to improve melt rate, waste loading, and waste throughput.

The Waste Form Compliance Plan (WCP) requires that new waste types be evaluated against the compositions previously documented in the Waste Form Qualification Report (WQR) Volume 1. If the compositions are outside of those already defined, then the glasses must be tested using the same protocols as the WCP glasses and the WQR updated. ${ }^{3}$ The higher waste loadings, new washing and frit development strategies, as well as the incorporation of excess material streams, pushed projected waste form compositions to a region that appeared to be compositionally different than the previously established region ${ }^{2}$ beginning with Sludge Batch 3 (SB3). Compositional difference can be observed in Table 1. More specifically, during processing of SB3, DWPF targeted a nominal waste loading (WL) of $38 \mathrm{wt} \%,{ }^{4}$ much higher than the planned $28 \mathrm{wt} \%$ sludge WL. This was done in an effort to maximize waste throughput, which is a function of melt rate and waste loading. In addition, the Liquid Waste Organization (LWO) Tank Farm operations utilized a target end point for sludge washing for SB3 to approximately $1.2 \mathrm{M} \mathrm{Na}^{+}$as compared to $0.5 \mathrm{M} \mathrm{Na}^{+}$for previous sludge batches in order to minimize water sent to the evaporator system and to accommodate the excess material streams from the high-level waste canyon. The result was a higher sodium-based sludge, which was compensated for using the strategic development of Frit 418. The combination of all of the changes ultimately transitioned the DWPF glass forming system outside the compositional region previously evaluated prior to radioactive operations. Specifically, note the lower $\mathrm{B}_{2} \mathrm{O}_{3}, \mathrm{CuO}, \mathrm{K}_{2} \mathrm{O}$, and $\mathrm{TiO}_{2}$ (due to abandonment of the Precipitate Hydrolysis process for salt treatment) and the higher $\mathrm{Li}_{2} \mathrm{O}$ and $\mathrm{Na}_{2} \mathrm{O}$ (due to frit and washing strategy changes) concentrations in Table 1. Therefore, to understand the impact of these changes and to ensure that the WQR projections were still adequate, a new glass transition temperature measurement and TTT diagram for this system was warranted. This task was initiated by the Task Technical Request HLW-DWPF-TTR-2006-0015, Revision 1, 5 and follows the Task Technical and Quality Assurance Plan WSRC-STI-2006-00004, Revision 1. ${ }^{6}$ 
Table 1. Waste Form Compositions of the Seven WCP Glasses, ${ }^{2,3}$ and the SB3-Frit 418 Glass*

\begin{tabular}{|c|c|c|c|c|c|c|c|c|}
\hline $\begin{array}{c}\text { Oxide } \\
(w t \%)\end{array}$ & $\begin{array}{c}\text { SB3-Frit } 418 \\
\text { Glass } \\
\text { Composition }\end{array}$ & Blend & HМ & Purex & $\begin{array}{c}\text { Batch } \\
\# 1\end{array}$ & $\begin{array}{c}\text { Batch } \\
\# 2\end{array}$ & $\begin{array}{c}\text { Batch } \\
\# 3\end{array}$ & $\begin{array}{c}\text { Batch } \\
\text { \#4 }\end{array}$ \\
\hline $\mathrm{Al}_{2} \mathrm{O}_{3}$ & 5.96 & 4.16 & 7.15 & 2.99 & 4.88 & 4.63 & 3.44 & 3.43 \\
\hline $\mathrm{B}_{2} \mathrm{O}_{3}$ & 5.16 & 8.05 & 7.03 & 10.33 & 7.78 & 7.88 & 7.69 & 8.14 \\
\hline $\mathrm{BaO}$ & 0.06 & 0.18 & 0.11 & 0.20 & 0.15 & 0.16 & 0.18 & 0.25 \\
\hline $\mathrm{CaO}$ & 1.13 & 1.03 & 1.01 & 1.09 & 1.22 & 1.08 & 0.99 & 0.84 \\
\hline $\mathrm{Ce}_{2} \mathrm{O}_{3}$ & 0.09 & - & - & - & - & - & - & - \\
\hline $\mathrm{Cr}_{2} \mathrm{O}_{3}$ & 0.09 & 0.13 & 0.09 & 0.15 & 0.11 & 0.13 & 0.14 & 0.14 \\
\hline $\mathrm{Cs}_{2} \mathrm{O}$ & - & 0.08 & 0.06 & 0.06 & 0.06 & 0.02 & 0.06 & 0.09 \\
\hline $\mathrm{CuO}$ & 0.04 & 0.44 & 0.25 & 0.42 & 0.40 & 0.42 & 0.40 & 0.45 \\
\hline $\mathrm{Fe}_{2} \mathrm{O}_{3}$ & 12.75 & 10.91 & 7.78 & 13.25 & 12.84 & 11.12 & 11.71 & 11.71 \\
\hline $\mathrm{K}_{2} \mathrm{O}$ & 0.08 & 3.67 & 2.21 & 3.41 & 3.33 & 3.38 & 3.40 & 3.86 \\
\hline $\mathrm{La}_{2} \mathrm{O}_{3}$ & 0.04 & - & - & - & - & - & - & - \\
\hline $\mathrm{Li}_{2} \mathrm{O}$ & 5.16 & 4.44 & 4.62 & 3.22 & 4.43 & 4.50 & 4.51 & 4.29 \\
\hline $\mathrm{MgO}$ & 1.39 & 1.41 & 1.49 & 1.41 & 1.42 & 1.42 & 1.42 & 1.43 \\
\hline $\mathrm{MnO}$ & 2.59 & 1.67 & 1.75 & 1.69 & 1.72 & 1.41 & 1.53 & 2.54 \\
\hline $\mathrm{MoO}_{3}$ & - & 0.15 & 0.22 & 0.08 & 0.11 & 0.17 & 0.12 & 0.20 \\
\hline $\mathrm{Na}_{2} \mathrm{O}$ & 13.88 & 9.13 & 8.56 & 12.62 & 9.00 & 9.21 & 9.01 & 9.16 \\
\hline $\mathrm{Nd}_{2} \mathrm{O}_{3}$ & - & 0.22 & 0.55 & 0.06 & 0.15 & 0.26 & 0.17 & 0.39 \\
\hline $\mathrm{NiO}$ & 0.69 & 0.89 & 0.41 & 1.19 & 0.75 & 0.90 & 1.05 & 1.06 \\
\hline $\mathrm{PbO}$ & 0.06 & - & - & - & - & - & - & - \\
\hline $\mathrm{RuO}_{2}$ & 0.02 & 0.03 & 0.04 & 0.01 & 0.02 & 0.04 & 0.03 & 0.05 \\
\hline $\mathrm{SiO}_{2}$ & 50.20 & 51.90 & 55.80 & 46.50 & 50.20 & 52.10 & 52.60 & 50.10 \\
\hline $\mathrm{SO}_{4}$ & 0.43 & - & - & - & - & - & - & - \\
\hline $\mathrm{TiO}_{2}$ & 0.01 & 0.89 & 0.56 & 0.68 & 0.68 & 0.69 & 0.68 & 1.03 \\
\hline $\mathrm{ZnO}$ & 0.06 & - & - & - & - & - & - & - \\
\hline $\mathrm{ZrO}_{2}$ & 0.11 & 0.14 & 0.33 & 0.05 & 0.10 & 0.17 & 0.12 & 0.22 \\
\hline SUM & 100.00 & 99.52 & 100.02 & 99.41 & 99.35 & 99.69 & 99.25 & 99.38 \\
\hline
\end{tabular}

* Prior to the WCP glass study, TTT diagrams were generated by C. Jantzen and D. Bickford on DWPF waste compositions containing $\mathrm{U}$ and $\mathrm{Th}$ (see Appendix A for compositions of these glasses). ${ }^{7,8}$ 


\subsection{Experimental Procedure}

\subsection{Glass Formulation}

A single stock of simulated SB3-Frit 418 glass was used to support the chemical and physical characterization associated with developing new TTT diagrams for the current compositional region. The current study was based on non-radioactive glasses in order to be consistent with the earlier TTT studies. ${ }^{2}$ More specifically, the sludge composition was renormalized without $\mathrm{U}_{3} \mathrm{O}_{8}$ and $\mathrm{ThO}_{2}$. The SB3 sludge composition used was a projected composition taken from a previous study (SRT-GPD2004-00069) $)^{9}$ and can be found along with the Frit 418 composition and the final renormalized glass composition in Table 2. This "nominal" SB3 composition was combined with Frit 418 at a waste loading of $38 \mathrm{wt} \%$. $\mathrm{RuO}_{2}$ was also added to the glass at $0.02 \mathrm{wt} \%$ because it is present as a minor component in the sludge. It was included in this testing because noble metals such as $\mathrm{RuO}_{2}$ are not fully soluble in the glass and will often serve as nucleation sites for crystallization. ${ }^{10}$ 
Table 2. Composition of the SB3 Nominal Sludge, Frit 418, Glass Composition at 38 wt \% WL and Final Non-Radioactive Renormalized Glass Composition with $\mathrm{RuO}_{2}$

\begin{tabular}{|c|c|c|c|c|}
\hline Oxide (wt \%) & SB3 Nominal ${ }^{9}$ & Frit 418 & $\begin{array}{c}\text { Glass } \\
\text { Composition } \\
(38 \text { wt \% WL) }\end{array}$ & $\begin{array}{c}\text { Non-Radioactive } \\
\text { Renormalized } \\
\text { Glass Composition } \\
\text { w/ } \mathbf{R u O}_{2}\end{array}$ \\
\hline $\mathrm{Al}_{2} \mathrm{O}_{3}$ & 15.072 & - & 5.73 & 5.96 \\
\hline $\mathrm{B}_{2} \mathrm{O}_{3}$ & - & 8.00 & 4.96 & 5.16 \\
\hline $\mathrm{BaO}$ & 0.147 & - & 0.06 & 0.06 \\
\hline $\mathrm{CaO}$ & 2.872 & - & 1.09 & 1.13 \\
\hline $\mathrm{Ce}_{2} \mathrm{O}_{3}$ & 0.237 & - & 0.09 & 0.09 \\
\hline $\mathrm{Cr}_{2} \mathrm{O}_{3}$ & 0.231 & - & 0.09 & 0.09 \\
\hline $\mathrm{CuO}$ & 0.095 & - & 0.04 & 0.04 \\
\hline $\mathrm{Fe}_{2} \mathrm{O}_{3}$ & 32.274 & - & 12.26 & 12.75 \\
\hline $\mathrm{K}_{2} \mathrm{O}$ & 0.207 & - & 0.08 & 0.08 \\
\hline $\mathrm{La}_{2} \mathrm{O}_{3}$ & 0.113 & - & 0.04 & 0.04 \\
\hline $\mathrm{Li}_{2} \mathrm{O}$ & - & 8.00 & 4.96 & 5.16 \\
\hline $\mathrm{MgO}$ & 3.514 & - & 1.34 & 1.39 \\
\hline $\mathrm{MnO}$ & 6.560 & - & 2.49 & 2.59 \\
\hline $\mathrm{Na}_{2} \mathrm{O}$ & 22.070 & 8.00 & 13.35 & 13.88 \\
\hline $\mathrm{NiO}$ & 1.735 & - & 0.66 & 0.69 \\
\hline $\mathrm{PbO}$ & 0.144 & - & 0.05 & 0.06 \\
\hline $\mathrm{RuO}_{2}$ & - & - & - & 0.02 \\
\hline $\mathrm{SiO}_{2}$ & 3.044 & 76.00 & 48.28 & 50.20 \\
\hline $\mathrm{SO}_{4}$ & 1.080 & - & 0.41 & 0.43 \\
\hline $\mathrm{ThO}_{2}$ & 0.034 & - & 0.01 & 0.00 \\
\hline $\mathrm{TiO}_{2}$ & 0.028 & - & 0.01 & 0.01 \\
\hline $\mathrm{U}_{3} \mathrm{O}_{8}$ & 10.116 & - & 3.84 & 0.00 \\
\hline $\mathrm{ZnO}$ & 0.155 & - & 0.06 & 0.06 \\
\hline $\mathrm{ZrO}_{2}$ & 0.270 & - & 0.10 & 0.11 \\
\hline SUM & 100.00 & 100.00 & 100.00 & 100.00 \\
\hline
\end{tabular}

\subsection{Glass Fabrication}

It should be noted that kilogram quantities of glass were required to support this task. This required multiple individual batches targeting the same composition to be melted and then combined into one large cache of glass. Glass was batched and melted following the standard SRNL procedures. ${ }^{11,12}$ The glass was prepared from the proper proportions of reagent-grade oxides, carbonates, boric acid, and salts in fourteen $300 \mathrm{~g}$ batches (numbered 1-14). The batch sheets and other experimental notes can be found in the laboratory notebook WSRC-NB-2006-00074. ${ }^{13}$ The raw materials were thoroughly mixed and placed into $95 \%$ platinum $/ 5 \%$ gold, $600 \mathrm{~mL}$ crucibles. The crucibles were placed into an electrically heated, high-temperature furnace at the target melt temperature of $1150{ }^{\circ} \mathrm{C}$. 
After an isothermal hold at $1150{ }^{\circ} \mathrm{C}$ for 1.0 hour, the crucibles were removed from the furnace and poured onto a clean, stainless steel plate and allowed to air cool (quench). The glasses were then crushed and pairs of the fourteen $300 \mathrm{~g}$ batches were combined into seven $600 \mathrm{~g}$ batches (named A$\mathrm{G}$ ) and re-melted at $1150{ }^{\circ} \mathrm{C}$ for $1.0 \mathrm{~h}$ of homogenization following the same procedure as above.

\subsection{Chemical Analysis}

To confirm that the as-fabricated glasses corresponded to the defined target composition, representative samples of each of the $600 \mathrm{~g}$ glass batches were submitted to the SRNL Process Science Analytical Laboratory (PSAL) for chemical analysis under the auspices of the analytical plan SRNL-SCS-2007-00004. ${ }^{14}$ The cations were analyzed by means of two dissolution techniques, sodium peroxide fusion (PF) and lithium-metaborate fusion (LM). The samples prepared by LM were used to measure aluminum $(\mathrm{Al})$, barium $(\mathrm{Ba})$, calcium $(\mathrm{Ca})$, cerium $(\mathrm{Ce})$, chromium $(\mathrm{Cr})$, copper $(\mathrm{Cu})$, iron $(\mathrm{Fe})$, potassium $(\mathrm{K})$, lanthanum $(\mathrm{La})$, magnesium $(\mathrm{Mg})$, manganese $(\mathrm{Mn})$, sodium, $(\mathrm{Na})$, nickel $(\mathrm{Ni})$, lead $(\mathrm{Pb})$, ruthenium $(\mathrm{Ru})$, sulfur $(\mathrm{S})$, silicon $(\mathrm{Si})$, titanium $(\mathrm{Ti})$, zinc $(\mathrm{Zn})$, and zirconium $(\mathrm{Zr})$ concentrations. Samples prepared by PF were used to measure boron (B) and lithium (Li) concentrations. Each glass was prepared in duplicate for each cation dissolution technique. All of the prepared samples were analyzed by Inductively Coupled Plasma - Atomic Emission Spectroscopy (ICP-AES) with the instrumentation being re-calibrated between the duplicate analyses. Glass standards were also intermittently measured to assess the performance of the ICP-AES instrument over the course of the analyses. Specifically, several samples of WCP Batch $1(\mathrm{BCH})^{15}$ were included in the sample analysis.

Results of the chemical analyses were reviewed before initiation of any measurements or heat treatments. ${ }^{16}$ The objective of the review was to facilitate a decision on the use of all or only a subset of the available batches of glass (A-G). The individual batches determined to be compositionally consistent could then be combined in order to create a cache of compositionally consistent glass that could be used to support the glass transition measurement and TTT study. The result of the statistical review of the measured compositions revealed some differences between the average measured concentrations of $\mathrm{MnO}$ for the SB3-TTT-G batch and the rest of the batches. Due to this irreconcilable difference, it was recommended that this batch be excluded from the cache of glass that was to be created. ${ }^{16}$ Eliminating batch $\mathrm{G}$ from the cache ensured that a compositionally consistent glass would be used to support programmatic objectives. Batches A-F were then combined and mixed thoroughly in one container where samples could subsequently be drawn for heat treatments.

\subsection{Glass Transition Temperature Determination}

A Netzsch 409 PC Luxx differential scanning calorimeter (DSC) was used to measure the glass transition temperature $\left(\mathrm{T}_{\mathrm{g}}\right)$ of the glass. The ASTM procedure E 1356 was also used as a guide for determining the $\mathrm{T}_{\mathrm{g}}{ }^{17}$ A portion of the quenched glass was ground and sieved to a particle size between 100 and 200 mesh. A heating rate of $20 \mathrm{~K} / \mathrm{min}$ was used to heat three separate samples from room temperature to $1000{ }^{\circ} \mathrm{C}$ in a platinum pan. The value of $\mathrm{T}_{\mathrm{g}}$ reported in this document was determined by the slope intercept method at the onset of the endothermic inflection and is the average of three separate tests.

\subsection{Heat Treatments}

In order to develop a TTT diagram for the SB3 Frit-418 glass composition, glasses were heat treated as follows. Approximately $30 \mathrm{~g}$ of glass from the chemically verified cache were placed in open platinum alloy crucibles and re-melted at $1150{ }^{\circ} \mathrm{C}$ for 45 minutes. Platinum alloy crucibles were used instead of alumina crucibles in order to minimize the possibility of alumina dissolution during longterm heat treatments. Durations shorter than one hour were used in order to minimize any volatilization of the chemically verified glass, yet still maintain a homogenized melt. After 45 
minutes, the crucibles were removed from the furnace and placed into separate furnaces preheated to the desired isothermal hold temperature. Once the desired duration of heat treatment was reached, crucibles were removed from the furnace and immersed in a shallow water bath to quickly cool or "quench" the glass. This process only exposed the exterior of the crucible to the water (i.e., water did not contact the glass). Each glass sample was heat treated at a unique time and temperature in order to cover the anticipated crystallization region. Sample names, temperatures and durations of heat treatments are listed in Table 3. An independent thermocouple and temperature recorder were used during heat treatments to ensure that the temperature remained relatively constant during the treatments. A sample of the glass was also heat treated according to the centerline canister cooling (CCC) temperature profile in order to simulate DWPF pouring conditions. ${ }^{18}$ The CCC glass, along with a sample of the original "quenched" glass (non-heat treated glass from the glass cache), was submitted along with all other heat treated samples for further analysis. 
Table 3. Sample Identification, Treatment Times and Temperatures

\begin{tabular}{|c|c|c|c|c|c|}
\hline Sample ID & $\begin{array}{c}\text { Temperature } \\
\left({ }^{\circ} \mathrm{C}\right)\end{array}$ & $\begin{array}{c}\text { Time } \\
\text { (hours) }\end{array}$ & Sample ID & $\begin{array}{c}\text { Temperature } \\
\left({ }^{\circ} \mathrm{C}\right)\end{array}$ & $\begin{array}{c}\text { Time } \\
\text { (hours) }\end{array}$ \\
\hline SB3-TTT-400-0.5HR & 400 & 0.5 & SB3-TTT-800-0.5HR & 800 & 0.5 \\
\hline SB3-TTT-400-1HR & 400 & 1 & SB3-TTT-800-1HR & 800 & 1 \\
\hline SB3-TTT-400-2HR & 400 & 2 & SB3-TTT-800-2HR & 800 & 2 \\
\hline SB3-TTT-400-3HR & 400 & 3 & SB3-TTT-800-3HR & 800 & 3 \\
\hline SB3-TTT-400-6HR & 400 & 6 & SB3-TTT-800-6HR & 800 & 6 \\
\hline SB3-TTT-400-12HR & 400 & 12 & SB3-TTT-800-12HR & 800 & 12 \\
\hline SB3-TTT-400-48HR & 400 & 48 & SB3-TTT-800-48HR & 800 & 48 \\
\hline SB3-TTT-500-0.5HR & 500 & 0.5 & SB3-TTT-800-192HR & 800 & 192 \\
\hline SB3-TTT-500-1HR & 500 & 1 & SB3-TTT-800-785HR ${ }^{*}$ & 800 & 785 \\
\hline SB3-TTT-500-2HR & 500 & 2 & SB3-TTT-900-0.5HR & 900 & 0.5 \\
\hline SB3-TTT-500-3HR & 500 & 3 & SB3-TTT-900-1HR & 900 & 1 \\
\hline SB3-TTT-500-6HR & 500 & 6 & SB3-TTT-900-2HR & 900 & 2 \\
\hline SB3-TTT-500-12HR & 500 & 12 & SB3-TTT-900-3HR & 900 & 3 \\
\hline SB3-TTT-500-48HR & 500 & 48 & SB3-TTT-900-6HR & 900 & 6 \\
\hline SB3-TTT-500-192HR & 500 & 192 & SB3-TTT-900-12HR & 900 & 12 \\
\hline SB3-TTT-500-768HR & 500 & 768 & SB3-TTT-900-48HR & 900 & 48 \\
\hline SB3-TTT-600-0.5HR & 600 & 0.5 & SB3-TTT-900-192HR & 900 & 192 \\
\hline SB3-TTT-600-1HR & 600 & 1 & SB3-TTT-900-768HR & 900 & 768 \\
\hline SB3-TTT-600-2HR & 600 & 2 & SB3-TTT-1000-0.5HR & 1000 & 0.5 \\
\hline SB3-TTT-600-3HR & 600 & 3 & SB3-TTT-1000-1HR & 1000 & 1 \\
\hline SB3-TTT-600-6HR & 600 & 6 & SB3-TTT-1000-2HR & 1000 & 2 \\
\hline SB3-TTT-600-12HR & 600 & 12 & SB3-TTT-1000-3HR & 1000 & 3 \\
\hline SB3-TTT-600-48HR & 600 & 48 & SB3-TTT-1000-6HR & 1000 & 6 \\
\hline SB3-TTT-600-192HR & 600 & 192 & SB3-TTT-1000-12HR & 1000 & 12 \\
\hline SB3-TTT-600-768HR & 600 & 768 & SB3-TTT-1000-48HR & 1000 & 48 \\
\hline SB3-TTT-700-0.5HR & 700 & 0.5 & SB3-TTT-1000-192HR & 1000 & 192 \\
\hline SB3-TTT-700-1HR & 700 & 1 & SB3-TTT-1000-785HR ${ }^{*}$ & 1000 & 785 \\
\hline SB3-TTT-700-2HR & 700 & 2 & SB3-TTT-1100-0.5HR & 1100 & 0.5 \\
\hline SB3-TTT-700-3HR & 700 & 3 & SB3-TTT-1100-1HR & 1100 & 1 \\
\hline SB3-TTT-700-6HR & 700 & 6 & SB3-TTT-1100-2HR & 1100 & 2 \\
\hline SB3-TTT-700-12HR & 700 & 12 & SB3-TTT-1100-3HR & 1100 & 3 \\
\hline SB3-TTT-700-48HR & 700 & 48 & SB3-TTT-1100-6HR & 1100 & 6 \\
\hline SB3-TTT-700-192HR & 700 & 192 & SB3-TTT-1100-12HR & 1100 & 12 \\
\hline SB3-TTT-700-785HR ${ }^{*}$ & 700 & 785 & SB3-TTT-1100-48HR & 1100 & 48 \\
\hline SB3-TTT-MIX-CCC & \multicolumn{2}{|c|}{$\mathrm{CCC}$} & SB3-TTT-MIX-ASR & \multicolumn{2}{|c|}{ quenched } \\
\hline
\end{tabular}

* These samples were accidentally left in the furnace for a slightly longer duration than the targeted 768 hours of treatment. 


\subsection{Phase Analysis (Qualitative and Quantitative)}

Glass samples were evaluated for crystallization using X-ray Diffraction (XRD). Depending on the type and extent of crystallization, the existence of crystalline phases in the glass can impact properties such as durability. The crystallization information may also provide insight into the potential liquidus temperature $\left(T_{L}\right)$ of the glass since crystals should not be identified above the $T_{L}$. Samples were run under conditions providing a detection limit of approximately $0.5 \mathrm{vol} \%$. That is, if crystals (or undissolved solids) were present at $0.5 \mathrm{vol} \%$ or greater, the diffractometer would not only be capable of detecting the crystals but would also allow a qualitative determination of the type of crystal(s) present. Jade $9.0^{\circ}$ software was used for phase analysis.

For those samples which exhibited a crystalline phase, quantitative XRD measurements were also conducted. A whole pattern Rietveld least squared refinement was conducted on samples using 10 wt $\%$ high purity alumina as an internal intensity standard. The Archimedes method was used to measure the density of the original glass ${ }^{19}$ and standard densities of the crystalline phases were referenced. Once both densities were determined, total volume percent crystallinity was calculated.

\subsection{Product Consistency Test}

The ASTM procedure C1285, PCT Method-A, ${ }^{20}$ was performed in triplicate on each isothermally heat treated, quenched and CCC glass to assess chemical durability. Also included in the experimental test matrix was the Environmental Assessment (EA) benchmark glass, ${ }^{21}$ the Approved Reference Material (ARM) glass and blanks from the sample cleaning batch. Samples were ground, washed and prepared following the standard procedure. ${ }^{20}$ Approximately fifteen milliliters of Type I ASTM water were added to $1.5 \mathrm{~g}$ of glass in stainless steel vessels. The vessels were closed, sealed and placed into an oven at $90 \pm 2{ }^{\circ} \mathrm{C}$ where the samples were maintained at temperature for 7 days \pm 3.4 hours. Once cooled, the resulting solutions were sampled (filtered and acidified), then labeled and analyzed by PSAL under the auspices of two analytical plans, one for the first set of glasses heat treated from 0.5 to 48 hours $^{22}$, and one for the second set of glasses heat treated longer than 48 hours ${ }^{23}$. The resulting solutions (leachates) were analyzed via ICP-AES for Si, B, Na, and Li release. Samples of a multi-element, standard solution were also included in the analytical plans as a check on the accuracy of the analytical instrumentation used for these measurements. Normalized release rates were calculated based on target and measured compositions using the average of the common logarithms of the leachate concentrations. 


\subsection{RESUlTS AND DisCUSSION}

\subsection{Chemical Composition}

The targeted and measured composition of the final glass cache, which was used for heat treatments are found in Table 4. No significant discrepancies were found between the targeted and analyzed compositions. This indicates the batching was successful and any sample taken from the glass cache will be representative of the measured composition. For a more detailed description of the statistical analysis of the glass batches, see the referenced report by Edwards. ${ }^{16}$

Table 4. Target and Overall Measured Concentrations by Weight Percent Oxide for the Cache of SB3/Frit-418 Glass $^{16}$

\begin{tabular}{|c|c|c|}
\hline Oxide & Target & Measured \\
\hline $\mathrm{Al}_{2} \mathrm{O}_{3}$ & 5.96 & 6.11 \\
\hline $\mathrm{B}_{2} \mathrm{O}_{3}$ & 5.16 & 5.12 \\
\hline $\mathrm{BaO}$ & 0.06 & 0.05 \\
\hline $\mathrm{CaO}$ & 1.14 & 1.09 \\
\hline $\mathrm{Ce}_{2} \mathrm{O}_{3}$ & 0.09 & 0.11 \\
\hline $\mathrm{Cr}_{2} \mathrm{O}_{3}$ & 0.09 & 0.09 \\
\hline $\mathrm{CuO}$ & 0.04 & 0.04 \\
\hline $\mathrm{Fe}_{2} \mathrm{O}_{3}$ & 12.75 & 12.39 \\
\hline $\mathrm{K}_{2} \mathrm{O}$ & 0.08 & 0.11 \\
\hline $\mathrm{La}_{2} \mathrm{O}_{3}$ & 0.05 & 0.04 \\
\hline $\mathrm{Li}_{2} \mathrm{O}$ & 5.16 & 5.24 \\
\hline $\mathrm{MgO}$ & 1.39 & 1.29 \\
\hline $\mathrm{MnO}$ & 2.59 & 2.77 \\
\hline $\mathrm{Na}_{2} \mathrm{O}$ & 13.88 & 13.95 \\
\hline $\mathrm{NiO}$ & 0.69 & 0.63 \\
\hline $\mathrm{PbO}$ & 0.06 & 0.05 \\
\hline $\mathrm{RuO}_{2}$ & 0.02 & 0.01 \\
\hline $\mathrm{SiO}_{2}$ & 50.20 & 50.46 \\
\hline $\mathrm{SO}_{4}$ & 0.43 & 0.40 \\
\hline $\mathrm{TiO}_{2}$ & 0.01 & 0.01 \\
\hline $\mathrm{ZnO}$ & 0.06 & 0.06 \\
\hline $\mathrm{ZrO}_{2}$ & 0.11 & 0.10 \\
\hline Sum & 100.00 & 100.12 \\
\hline
\end{tabular}




\subsection{Glass Transition Temperature $\left(T_{g}\right)$}

The glass transition onset temperature was measured using DSC. The DSC response in $\mu \mathrm{V}$ as a function of temperature in ${ }^{\circ} \mathrm{C}$ and the slope-intercept determination are shown in Figure 1. The onset of $\mathrm{T}_{\mathrm{g}}$ was determined to occur at $443 \pm 3{ }^{\circ} \mathrm{C}$. The $\mathrm{T}_{\mathrm{g}}$ is an indicator of the approximate temperature where the supercooled liquid converts to a solid on cooling or conversely, where the solid begins to behave as a viscoelastic solid on heating. This is extremely important because crystallization cannot occur below the onset of $T_{g}$. These results are consistent with the XRD data for this study, as no crystallization was detected in any of the samples treated at $400{ }^{\circ} \mathrm{C}$. The $\mathrm{T}_{\mathrm{g}}$ of the current glass is also similar to the measured glass transition ranges for the seven WCP glasses. The glass transition range for those glasses were between $418{ }^{\circ} \mathrm{C}$ and $460{ }^{\circ} \mathrm{C} .{ }^{24}$ A measured $\mathrm{T}_{\mathrm{g}}$ of $443{ }^{\circ} \mathrm{C}$ also satisfies the requirement for glass stability as stated in the WCP and is above the lower limit of $400{ }^{\circ} \mathrm{C}$. $^{3}$

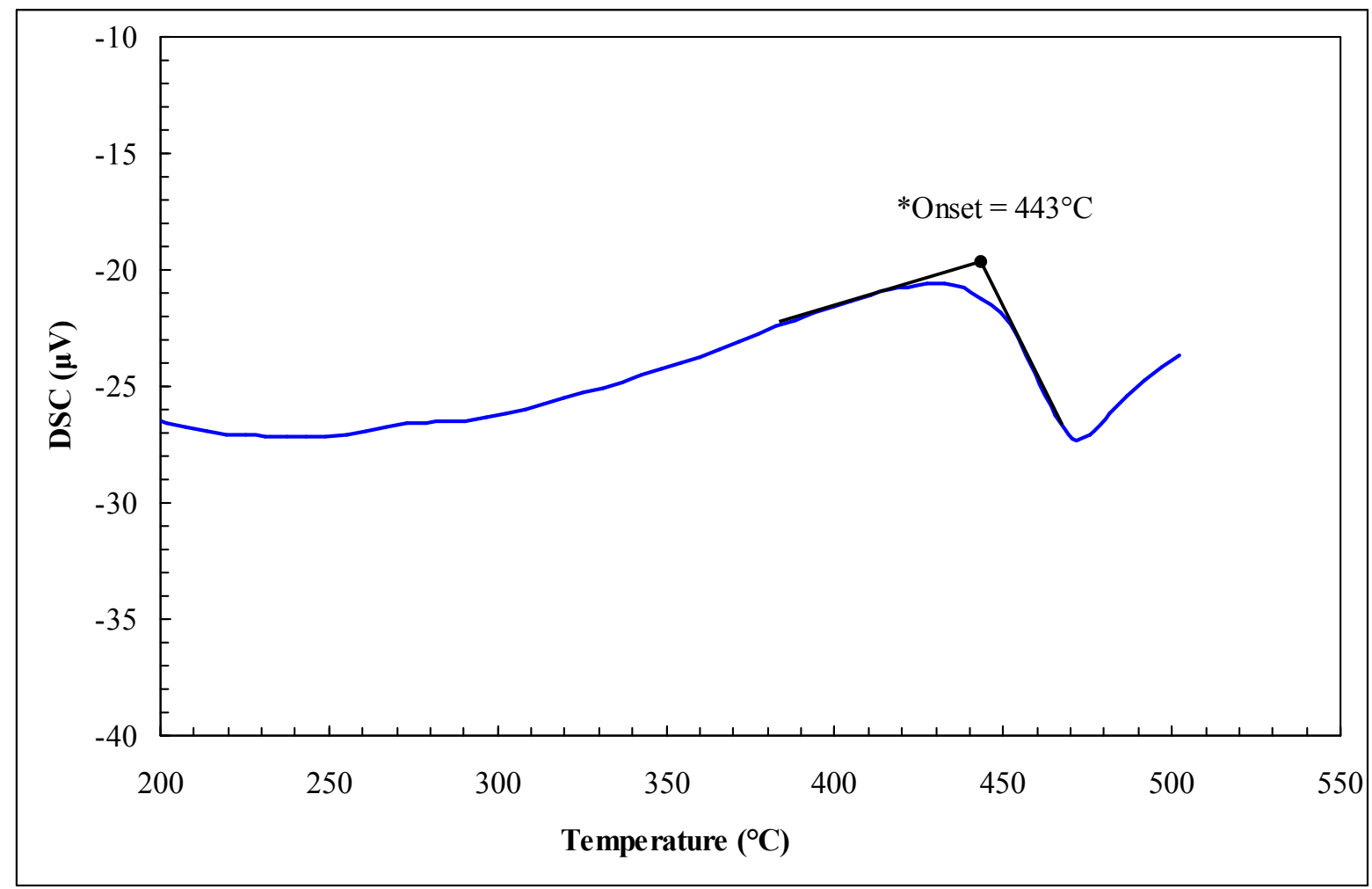

Figure 1. The DSC curve and glass transition temperature determination by slope intercept method. $T_{g}$ was determined to occur at $443 \pm 3^{\circ} \mathrm{C}$ at a $20 \mathrm{~K} / \mathrm{min}$ heating rate.

\subsection{Phase Analysis (X-ray Diffraction)}

XRD was completed on every heat treated sample as well as quenched and CCC heat treated samples. Table 5 lists the results of the XRD analysis on all of the samples. Only eleven samples were found to contain a crystalline phase or multiple crystalline phases. Crystallization only occurred at extended durations of heat treatment time (48 hours and longer) at temperatures between $600{ }^{\circ} \mathrm{C}$ and $900{ }^{\circ} \mathrm{C}$. No crystallization was detected for this glass composition at temperatures below $600{ }^{\circ} \mathrm{C}$, above $900{ }^{\circ} \mathrm{C}$, at heat treatment times less than 48 hours, or in the quenched or CCC treated glass samples. Phases that could potentially affect the durability of the residual glass such as nepheline $\left(\mathrm{NaAlSiO}_{4}\right)$ 
and lithium metasilicate $\left(\mathrm{Li}_{2} \mathrm{SiO}_{3}\right)$ were present in samples treated at $600{ }^{\circ} \mathrm{C}$ for 192 and 768 hours and samples treated at $700{ }^{\circ} \mathrm{C}$ for 48,192 and 785 hours. Sodium transition metal silicate-based phases, which included aegirine $\left(\mathrm{NaFe}^{3+}\left(\mathrm{SiO}_{3}\right)_{2}\right)$ (which is synonymous to acmite) and krinovite $\left(\mathrm{NaMg}_{2} \mathrm{CrSi}_{3} \mathrm{O}_{10}\right)$, sodium aluminosilicate-based phases such as albite $\left(\mathrm{NaAlSi}_{3} \mathrm{O}_{8}\right)$ and nepheline $\left(\mathrm{NaAlSiO}_{4}\right)$, as well as lithium metasilicate $\left(\mathrm{Li}_{2} \mathrm{SO}_{3}\right)$ were detected in samples treated at $600{ }^{\circ} \mathrm{C}$ for 192 and 768 hours and samples treated at $700{ }^{\circ} \mathrm{C}$ and $800{ }^{\circ} \mathrm{C}$ for 48,192 and 785 hours. Samples treated at $800{ }^{\circ} \mathrm{C}$ and $900{ }^{\circ} \mathrm{C}$, where the spinel-type phase trevorite $\left(\mathrm{NiFe}_{2} \mathrm{O}_{4}\right)$ crystallized, are not expected to exhibit a significant decrease in durability for the remaining glass.

As compared to the phases precipitated in the WCP glasses previously studied, all crystalline phases detected were the same, with the exception of krinovite and albite. These two phases were only detected in one sample treated at $700^{\circ} \mathrm{C}$ for 48 hours. These phases do however remain in the same crystalline families and are similar in composition to aegirine and nepheline. This confirms that no new phase end-members were formed in the SB3-Frit 418 glass even though new waste processing strategies were implemented. 
SRNL-STI-2009-00025

Revision 0

Table 5. Crystalline Phases of the Heat Treated Sample Detected With X-ray Diffraction

\begin{tabular}{|c|c|c|c|}
\hline Name & Crystalline Phase(s) & Name & Crystalline Phase(s) \\
\hline "SB3-TTT-400-0.5HR & Amorphous & "SB3-TTT-800-0.5HR & amorphous \\
\hline SB3-TTT-400-1HR & Amorphous & SB3-TTT-800-1HR & amorphous \\
\hline SB3-TTT-400-2HR & Amorphous & SB3-TTT-800-2HR & amorphous \\
\hline SB3-TTT-400-3HR & Amorphous & SB3-TTT-800-3HR & amorphous \\
\hline SB3-TTT-400-6HR & Amorphous & SB3-TTT-800-6HR & amorphous \\
\hline SB3-TTT-400-12HR & Amorphous & SB3-TTT-800-12HR & amorphous \\
\hline SB3-TTT-400-48HR & Amorphous & SB3-TTT-800-48HR & Aegirine $\left(\mathrm{NaFe}^{3+}\left(\mathrm{SiO}_{3}\right)_{2}\right)$ \\
\hline SB3-TTT-500-0.5HR & Amorphous & SB3-TTT-800-192HR & Trevorite $\left(\mathrm{NiFe}_{2} \mathrm{O}_{4}\right)$ \\
\hline SB3-TTT-500-1HR & Amorphous & SB3-TTT-800-785HR & $\begin{array}{c}\text { Trevorite }\left(\mathrm{NiFe}_{2} \mathrm{O}_{4}\right) \\
\text { Aegirine }\left(\mathrm{NaFe}^{3+}\left(\mathrm{SiO}_{3}\right)_{2}\right)\end{array}$ \\
\hline SB3-TTT-500-2HR & Amorphous & SB3-TTT-900-0.5HR & amorphous \\
\hline SB3-TTT-500-3HR & Amorphous & SB3-TTT-900-1HR & amorphous \\
\hline SB3-TTT-500-6HR & Amorphous & SB3-TTT-900-2HR & amorphous \\
\hline SB3-TTT-500-12HR & Amorphous & SB3-TTT-900-3HR & amorphous \\
\hline SB3-TTT-500-48HR & Amorphous & SB3-TTT-900-6HR & amorphous \\
\hline SB3-TTT-500-192HR & Amorphous & SB3-TTT-900-12HR & amorphous \\
\hline SB3-TTT-500-768HR & Amorphous & SB3-TTT-900-48HR & Trevorite $\left(\mathrm{NiFe}_{2} \mathrm{O}_{4}\right)$ \\
\hline SB3-TTT-600-0.5HR & Amorphous & SB3-TTT-900-192HR & Trevorite $\left(\mathrm{NiFe}_{2} \mathrm{O}_{4}\right)$ \\
\hline SB3-TTT-600-1HR & Amorphous & SB3-TTT-900-768HR & Trevorite $\left(\mathrm{NiFe}_{2} \mathrm{O}_{4}\right)$ \\
\hline SB3-TTT-600-2HR & Amorphous & SB3-TTT-1000-0.5HR & amorphous \\
\hline SB3-TTT-600-3HR & Amorphous & SB3-TTT-1000-1HR & amorphous \\
\hline SB3-TTT-600-6HR & Amorphous & SB3-TTT-1000-2HR & amorphous \\
\hline SB3-TTT-600-12HR & amorphous & SB3-TTT-1000-3HR & amorphous \\
\hline SB3-TTT-600-48HR & amorphous & SB3-TTT-1000-6HR & amorphous \\
\hline SB3-TTT-600-192HR & $\begin{array}{l}\text { Lithium Silicate }\left(\mathrm{Li}_{2} \mathrm{SiO}_{3}\right), \\
\text { Aegirine }\left(\mathrm{NaFe}^{3+}\left(\mathrm{SiO}_{3}\right)_{2}\right) \\
\text { Nepheline }\left(\mathrm{NaAlSiO}_{4}\right)\end{array}$ & SB3-TTT-1000-12HR & amorphous \\
\hline SB3-TTT-600-768HR & $\begin{array}{c}\text { Aegirine }\left(\mathrm{NaFe}^{3+}\left(\mathrm{SiO}_{3}\right)_{2}\right), \\
\text { Lithium Silicate }\left(\mathrm{Li}_{2} \mathrm{SiO}_{3}\right), \\
\text { Nepheline }\left(\mathrm{NaAlSiO}_{4}\right)\end{array}$ & SB3-TTT-1000-48HR & amorphous \\
\hline SB3-TTT-700-0.5HR & amorphous & SB3-TTT-1000-192HR & amorphous \\
\hline SB3-TTT-700-1HR & amorphous & SB3-TTT-1000-785HR & amorphous \\
\hline SB3-TTT-700-2HR & amorphous & SB3-TTT-1100-0.5HR & amorphous \\
\hline SB3-TTT-700-3HR & amorphous & SB3-TTT-1100-1HR & amorphous \\
\hline SB3-TTT-700-6HR & amorphous & SB3-TTT-1100-2HR & amorphous \\
\hline SB3-TTT-700-12HR & amorphous & SB3-TTT-1100-3HR & amorphous \\
\hline SB3-TTT-700-48HR & $\begin{array}{c}\text { Aegirine }\left(\mathrm{NaFe}^{3+}\left(\mathrm{SiO}_{3}\right)_{2}\right), \\
\text { Lithium Silicate }\left(\mathrm{Li}_{2} \mathrm{SiO}_{3}\right), \\
\text { Albite }\left(\mathrm{NaAlSi}_{3} \mathrm{O}_{8}\right) \\
\text { Krinovite }\left(\mathrm{NaMg}_{2} \mathrm{CrSi}_{3} \mathrm{O}_{10}\right)\end{array}$ & SB3-TTT-1100-6HR & amorphous \\
\hline SB3-TTT-700-192HR & $\begin{array}{c}\text { Lithium Silicate }(\mathrm{Li} 2 \mathrm{SiO} 3) \\
\text { Aegirine }\left(\mathrm{NaFe}^{3+}\left(\mathrm{SiO}_{3}\right)_{2}\right)\end{array}$ & SB3-TTT-1100-12HR & amorphous \\
\hline SB3-TTT-700-785HR & $\begin{array}{c}\text { Lithium Silicate }\left(\mathrm{Li}_{2} \mathrm{SiO}_{3}\right), \\
\text { Aegirine }\left(\mathrm{NaFe}^{3+}\left(\mathrm{SiO}_{3}\right)_{2}\right)\end{array}$ & SB3-TTT-1100-48HR & amorphous \\
\hline SB3-TTT-MIX-CCC & amorphous & SB3-TTT-MIX-ASR & amorphous \\
\hline
\end{tabular}


For the eleven samples which contained crystalline phases, quantitative measurements of each of the phases were completed. The results of the quantitative XRD analysis can be found in Table 6 . In this table, volume percent crystallinity for each phase detected by XRD, as well as total crystallinity, is listed. The quantitative results show that the maximum amount of crystallization (for those times and temperatures tested) occurred at $600{ }^{\circ} \mathrm{C}$ for 768 hours of treatment. After that duration of treatment, approximately $53 \mathrm{vol} \%$ of the sample was crystalline. The next worst region occurred at $700{ }^{\circ} \mathrm{C}$ with approximately $29 \mathrm{vol} \%$ crystals after 785 hours of treatment. Heat treatments at 800 and $900{ }^{\circ} \mathrm{C}$ resulted in fewer crystals being formed than at 600 and $700{ }^{\circ} \mathrm{C}$.

Table 6. Quantitative X-ray Diffraction Results

\begin{tabular}{|c|c|c|c|c|}
\hline Sample ID & Phases & $\begin{array}{c}\text { Vol \% } \\
\text { Crystalline }\end{array}$ & $\begin{array}{l}\text { Total Vol \% } \\
\text { Crystalline }\end{array}$ & $\begin{array}{c}\text { Vol \% } \\
\text { Amorphous }\end{array}$ \\
\hline \multirow{3}{*}{ SB3-TTT-600-192HR } & Lithium Silicate $\left(\mathrm{Li}_{2} \mathrm{SiO}_{3}\right)$ & 8.29 & \multirow{3}{*}{17.33} & \multirow{3}{*}{82.67} \\
\hline & Aegirine $\left(\mathrm{NaFe}^{3+}\left(\mathrm{SiO}_{3}\right)_{2}\right)$ & 3.06 & & \\
\hline & Nepheline $\left(\mathrm{NaAlSiO}_{4}\right)$ & 5.97 & & \\
\hline \multirow{3}{*}{ SB3-TTT-600-768HR } & Aegirine $\left(\mathrm{NaFe}^{3+}\left(\mathrm{SiO}_{3}\right)_{2}\right)$ & 32.07 & \multirow{3}{*}{52.95} & \multirow{3}{*}{47.05} \\
\hline & Lithium Silicate $\left(\mathrm{Li}_{2} \mathrm{SiO}_{3}\right)$ & 10.86 & & \\
\hline & Nepheline $\left(\mathrm{NaAlSiO}_{4}\right)$ & 10.01 & & \\
\hline \multirow[t]{2}{*}{ SB3-TTT-700-48HR } & $\begin{array}{l}\text { Aegirine }\left(\mathrm{NaFe}^{3+}\left(\mathrm{SiO}_{3}\right)_{2}\right) \text { and } \\
\text { Krinovite }\left(\mathrm{NaMg}_{2} \mathrm{CrSi}_{3} \mathrm{O}_{10}\right)^{*}\end{array}$ & 13.49 & \multirow[t]{2}{*}{14.96} & \multirow[t]{2}{*}{85.04} \\
\hline & Lithium Silicate $\left(\mathrm{Li}_{2} \mathrm{SiO}_{3}\right)$ & 1.47 & & \\
\hline \multirow{2}{*}{ SB3-TTT-700-192HR } & ב Lithium Silicate $\left(\mathrm{Li}_{2} \mathrm{SiO}_{3}\right)$ & 7.41 & \multirow{2}{*}{26.07} & \multirow{2}{*}{73.93} \\
\hline & Aegirine $\left(\mathrm{NaFe}^{3+}\left(\mathrm{SiO}_{3}\right)_{2}\right)$ & 18.66 & & \\
\hline \multirow{2}{*}{ SB3-TTT-700-785HR } & Lithium Silicate $\left(\mathrm{Li}_{2} \mathrm{SiO}_{3}\right)$ & 9.67 & \multirow{2}{*}{28.84} & \multirow{2}{*}{71.16} \\
\hline & Aegirine $\left(\mathrm{NaFe}^{3+}\left(\mathrm{SiO}_{3}\right)_{2}\right)$ & 19.17 & & \\
\hline SB3-TTT-800-48HR & Aegirine $\left(\mathrm{NaFe}^{3+}\left(\mathrm{SiO}_{3}\right)_{2}\right)$ & 0.67 & 0.67 & 99.33 \\
\hline 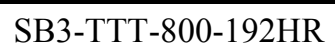 & Trevorite $\left(\mathrm{NiFe}_{2} \mathrm{O}_{4}\right)$ & 0.99 & 0.99 & 99.01 \\
\hline \multirow{2}{*}{ SB3-TTT-800-785HR } & Trevorite $\left(\mathrm{NiFe}_{2} \mathrm{O}_{4}\right)$ & 2.55 & \multirow{2}{*}{3.60} & \multirow{2}{*}{96.40} \\
\hline & Aegirine $\left(\mathrm{NaFe}^{3+}\left(\mathrm{SiO}_{3}\right)_{2}\right)$ & 1.05 & & \\
\hline SB3-TTT-900-48HR & Trevorite $\left(\mathrm{NiFe}_{2} \mathrm{O}_{4}\right)$ & 0.60 & 0.60 & 99.40 \\
\hline SB3-TTT-900-192HR & Trevorite $\left(\mathrm{NiFe}_{2} \mathrm{O}_{4}\right)$ & 1.39 & 1.39 & 98.61 \\
\hline SB3-TTT-900-768HR & Trevorite $\left(\mathrm{NiFe}_{2} \mathrm{O}_{4}\right)$ & 0.60 & 0.60 & 99.40 \\
\hline
\end{tabular}

* The crystalline phases formed in this sample were complex and formed a solid-solution which made quantitative analyses difficult and had to be estimated.

After evaluating the XRD data, a time-temperature-transformation diagram could be developed (Figure 2). Qualitative phase analysis results were used to determine the preferred regions for crystallization. All heat treated glass samples were plotted on a temperature (in degrees Celsius) versus log time (in hours) graph. Those samples which contained crystals are represented by a black diamond. All samples which remained amorphous after the specified treatment temperature and duration are represented by a solid circle. The location and arrangement of the crystalline phase data points are used to define the estimated location of phase transformation lines, which indicate the time and temperature where the phase transitions occur. These phase regions are outlined by five different 
dashed colored lines as noted in the legend in Figure 2. A point encompassed by overlapping regions indicates multiple phases detected in a single sample. The profile of the CCC curve is also plotted on the TTT diagram for reference.

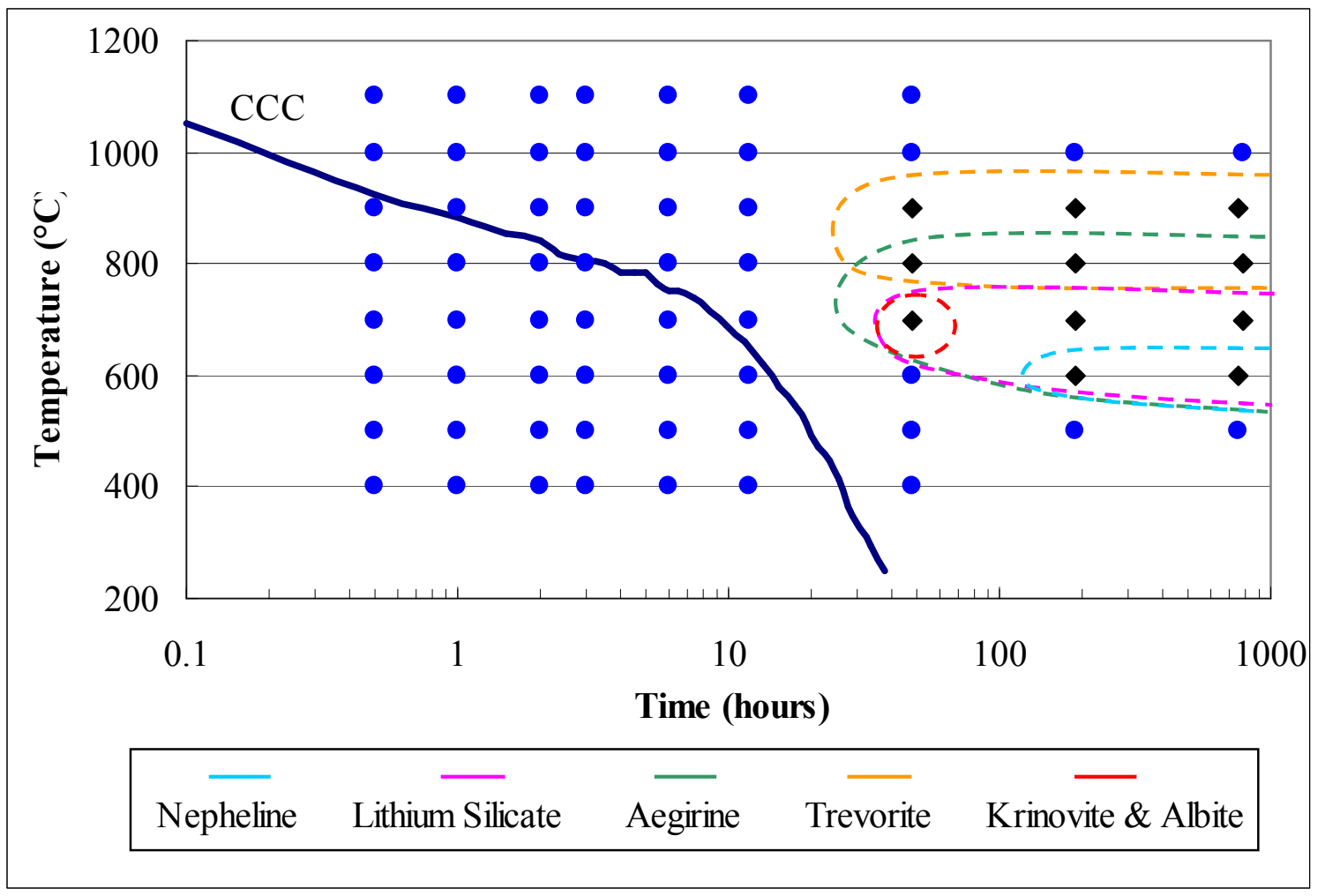

Figure 2. Time-Temperature-Transformation Diagram for SB3/Frit-418 Glass

The TTT diagram for SB3 - Frit 418 at a 38 wt \% WL has four main crystalline phases; nepheline, lithium silicate, aegirine, and trevorite, and two minor phases: krinovite and a very small amount of albite. The entire crystallization region was encompassed by either the spinel-type phase, trevorite, or iron silicate-based aegirine. At lower temperatures $\left(700{ }^{\circ} \mathrm{C}\right.$ and $600{ }^{\circ} \mathrm{C}$ ), lithium silicate and nepheline formed as well as aegirine. One sample at $700{ }^{\circ} \mathrm{C}$ and 48 hours of treatment contained a significant concentration of complex crystalline solutions ( $>14 \mathrm{vol} \%$ total) consisting of krinovite, aegirine, albite as well as lithium silicate.

It is important to note that all crystallization occurred at times significantly beyond the heat-treatment profile represented by the CCC curve. This suggests that this glass is extremely stable and resistant to crystallization upon simulation of prototypic melter and pouring operations in DWPF represented by a CCC profile-treated glass. Also as listed in Table 5, the CCC treated sample complements the results of the above statement and TTT diagram, and exhibits no detectable crystallization. Also note that the two potentially durability affecting phases, nepheline and lithium silicate did not occur autonomously. Those phase regions occurred in the major phase region of aegirine and were also present with albite and krinovite. Although no observed in past studies, this suggests that major silicate phases such as lithium silicate and nepheline could possibly be nucleated by aegirine at these lower temperatures. 
The phases formed under the treatment conditions discussed are similar to those established by the previous WCP glass study. ${ }^{2}$ Trevorite was found to occur most often at the higher treatment temperatures, while silicate and sodium aluminosilicate phase regions (lithium metasilicate and nepheline specifically) occurred around $600-700{ }^{\circ} \mathrm{C}$ most frequently. Even with the different blending, washing and frit development strategies, it appears that crystallization regions are very similar to those previously studied. ${ }^{2}$

\subsection{Chemical Durability (PCT Test)}

The normalized releases for all heat treated samples as indicated by the PCT are listed in Table 7. Overall, only one heat treated sample exhibited normalized releases greater than those of EA glass which is $16.695 \mathrm{~g} / \mathrm{L}$ for $\mathrm{B}, 9.565 \mathrm{~g} / \mathrm{L}$ for $\mathrm{Li}, 13.346 \mathrm{~g} / \mathrm{L}$ for Na and $3.922 \mathrm{~g} / \mathrm{L}$ for $\mathrm{Si}^{21}$ The glass sample heat treated at $600{ }^{\circ} \mathrm{C}$ for 768 hours had normalized releases of $10.2,58.5,22.5$, and $4.57 \mathrm{~g} / \mathrm{L}$ of $\mathrm{Li}, \mathrm{B}, \mathrm{Na}$ and $\mathrm{Si}$ respectively. Based on the XRD results, this sample approximately $53 \mathrm{vol} \%$ overall crystallization of nepheline, aegirine, and lithium metasilicate. Presence of these crystalline phases have all historically been shown to have a negative impact on glass durability as measured by the PCT. ${ }^{2}$ Keep in mind that this treatment temperature and time are not typical and would even be hard to obtain during an atypical accident scenario. PCT results similar to these samples would not be reproducible during normal processing at the DWPF for this glass.

A sample treated for a shorter duration (192 hours) at $600{ }^{\circ} \mathrm{C}$ had the next highest normalized B release at $3.76 \mathrm{~g} / \mathrm{L}$, which remains below that of EA glass. In fact, only those samples which contained lithium metasilicate and/or nepheline had normalized releases of B higher than $1.4 \mathrm{~g} / \mathrm{L}$. The exception is the sample treated at $600{ }^{\circ} \mathrm{C}$ for 48 hours, which was labeled "amorphous" based on XRD results. The normalized $B$ release was slightly elevated to $1.73 \mathrm{~g} / \mathrm{L}$ and increased significantly for the next longest treatment time of $600{ }^{\circ} \mathrm{C}$. This suggests the presence of nepheline or lithium metasilicate in the 48 hour sample at levels below $0.5 \mathrm{vol} \%$, which is the approximate detection limit of the X-ray diffractometer used for analysis.

In order to emphasize the change in PCT response as a function of crystalline phase, Table 8 lists the volume percent crystal and phase type parallel to the normalized release of B for the respective sample. When aegirine or spinel type phases such as trevorite are the only phases present, the normalized B release is $1.1 \mathrm{~g} / \mathrm{L}$ or less. The six samples in which this occurs have been treated at the higher temperatures of $800{ }^{\circ} \mathrm{C}$ and $900{ }^{\circ} \mathrm{C}$ and have a minimal volume percent of total crystallinity $(\leq 3.6$ vol \%). Those samples, whose normalized B release is elevated, contain higher volume fractions of total crystals and nepheline and/or lithium metasilicate phases.

To better illustrate the PCT results, normalized release was graphed three-dimensionally as a function of treatment time and temperature. Figures 3-6 represent the PCT response of the entire heat treated matrix of glass samples. As shown, normalized releases are only elevated at times of 48 hours and longer at temperatures between $600{ }^{\circ} \mathrm{C}$ and $700{ }^{\circ} \mathrm{C}$. This also corresponds to the region where nondurable crystalline phases were detected. 
Table 7. PCT Response of the Heat Treated Samples

\begin{tabular}{|c|c|c|c|c|c|c|c|c|c|}
\hline \multirow{2}{*}{ Sample ID } & \multicolumn{4}{|c|}{ Normalized Release (g/L) } & \multirow{2}{*}{ Sample ID } & \multicolumn{4}{|c|}{ Normalized Release $(\mathrm{g} / \mathrm{L})$} \\
\hline & $\mathbf{L i}$ & B & $\mathbf{N a}$ & $\mathbf{S i}$ & & $\mathbf{L i}$ & B & $\mathbf{N a}$ & $\mathbf{S i}$ \\
\hline EA & 10.22 & 19.41 & 14.51 & 4.20 & ARM & 0.62 & 0.53 & 0.57 & 0.29 \\
\hline SB3-TTT-400-0.5HR & 0.95 & 1.03 & 1.16 & 0.62 & SB3-TTT-800-0.5HR & 0.92 & 1.02 & 1.08 & 0.60 \\
\hline SB3-TTT-400-1HR & 0.99 & 1.09 & 1.13 & 0.63 & SB3-TTT-800-1HR & 0.97 & 1.07 & 1.15 & 0.66 \\
\hline SB3-TTT-400-2HR & 0.97 & 1.05 & 1.11 & 0.63 & SB3-TTT-800-2HR & 0.97 & 1.05 & 1.20 & 0.63 \\
\hline SB3-TTT-400-3HR & 0.93 & 1.00 & 1.11 & 0.60 & SB3-TTT-800-3HR & 0.96 & 1.15 & 1.11 & 0.62 \\
\hline SB3-TTT-400-6HR & 0.93 & 1.01 & 1.06 & 0.59 & SB3-TTT-800-6HR & 0.93 & 1.04 & 1.11 & 0.63 \\
\hline SB3-TTT-400-12HR & 0.92 & 1.01 & 1.02 & 0.61 & SB3-TTT-800-12HR & 1.00 & 1.07 & 1.21 & 0.64 \\
\hline SB3-TTT-400-48HR & 0.92 & 0.98 & 1.06 & 0.60 & SB3-TTT-800-48HR & 0.93 & 1.00 & 1.09 & 0.62 \\
\hline SB3-TTT-500-0.5HR & 0.95 & 1.04 & 1.14 & 0.63 & SB3-TTT-800-192HR & 0.95 & 1.14 & 1.15 & 0.67 \\
\hline SB3-TTT-500-1HR & 0.94 & 1.06 & 1.11 & 0.65 & SB3-TTT-800-785HR & 0.89 & 0.94 & 1.11 & 0.63 \\
\hline SB3-TTT-500-2HR & 0.95 & 1.06 & 1.19 & 0.62 & SB3-TTT-900-0.5HR & 0.96 & 1.07 & 1.14 & 0.65 \\
\hline SB3-TTT-500-3HR & 0.97 & 1.08 & 1.16 & 0.63 & SB3-TTT-900-1HR & 0.99 & 1.08 & 1.22 & 0.65 \\
\hline SB3-TTT-500-6HR & 0.93 & 1.05 & 1.10 & 0.64 & SB3-TTT-900-2HR & 0.95 & 1.06 & 1.11 & 0.62 \\
\hline SB3-TTT-500-12HR & 0.95 & 1.05 & 1.18 & 0.63 & SB3-TTT-900-3HR & 0.94 & 1.04 & 1.11 & 0.63 \\
\hline SB3-TTT-500-48HR & 0.95 & 1.05 & 1.13 & 0.62 & SB3-TTT-900-6HR & 0.97 & 1.07 & 1.22 & 0.64 \\
\hline SB3-TTT-500-192HR & 0.91 & 1.02 & 1.13 & 0.65 & $\begin{array}{l}\text { SB3-TTT-900-12HR } \\
\end{array}$ & 0.91 & 1.00 & 1.12 & 0.60 \\
\hline SB3-TTT-500-768HR & 0.99 & 1.09 & 1.16 & 0.69 & SB3-TTT-900-48HR & 0.90 & 1.00 & 1.09 & 0.63 \\
\hline SB3-TTT-600-0.5HR & 0.98 & 1.07 & 1.17 & 0.66 & SB3-TTT-900-192HR & 0.90 & 1.00 & 1.11 & 0.64 \\
\hline SB3-TTT-600-1HR & 0.96 & 1.04 & 1.17 & 0.62 & SB3-TTT-900-768HR & 0.90 & 1.00 & 1.10 & 0.65 \\
\hline SB3-TTT-600-2HR & 0.93 & 1.02 & 1.10 & 0.61 & SB3-TTT-1000-0.5HR & 1.00 & 1.10 & 1.22 & 0.65 \\
\hline SB3-TTT-600-3HR & 0.97 & 1.07 & 1.16 & 0.65 & SB3-TTT-1000-1HR & 0.91 & 1.00 & 1.09 & 0.60 \\
\hline SB3-TTT-600-6HR & 0.95 & 1.04 & 1.16 & 0.63 & SB3-TTT-1000-2HR & 0.97 & 1.09 & 1.15 & 0.65 \\
\hline SB3-TTT-600-12HR & 0.98 & 1.07 & 1.17 & 0.63 & SB3-TTT-1000-3HR & 0.99 & 1.08 & 1.19 & 0.64 \\
\hline SB3-TTT-600-48HR & 2.27 & 1.73 & 1.62 & 0.97 & SB3-TTT-1000-6HR & 0.93 & 1.03 & 1.11 & 0.60 \\
\hline SB3-TTT-600-192HR & 4.73 & 3.76 & 2.70 & 1.75 & SB3-TTT-1000-12HR & 0.96 & 1.09 & 1.16 & 0.66 \\
\hline SB3-TTT-600-768HR & 10.18 & 58.49 & 22.50 & 4.57 & SB3-TTT-1000-48HR & 0.95 & 1.05 & 1.18 & 0.64 \\
\hline SB3-TTT-700-0.5HR & 0.96 & 1.05 & 1.20 & 0.64 & SB3-TTT-1000-192HR & 0.96 & 1.06 & 1.13 & 0.67 \\
\hline SB3-TTT-700-1HR & 0.97 & 1.06 & 1.13 & 0.61 & SB3-TTT-1000-785HR & 0.90 & 0.94 & 1.06 & 0.64 \\
\hline SB3-TTT-700-2HR & 1.01 & 1.13 & 1.23 & 0.68 & SB3-TTT-1100-0.5HR & 0.93 & 1.07 & 1.09 & 0.61 \\
\hline SB3-TTT-700-3HR & 0.96 & 1.06 & 1.15 & 0.63 & SB3-TTT-1100-1HR & 0.94 & 1.05 & 1.11 & 0.62 \\
\hline SB3-TTT-700-6HR & 0.91 & 1.03 & 1.08 & 0.60 & SB3-TTT-1100-2HR & 1.01 & 1.09 & 1.25 & 0.66 \\
\hline SB3-TTT-700-12HR & 0.98 & 1.09 & 1.17 & 0.66 & SB3-TTT-1100-3HR & 0.93 & 1.04 & 1.10 & 0.62 \\
\hline SB3-TTT-700-48HR & 2.46 & 1.46 & 1.60 & 1.14 & SB3-TTT-1100-6HR & 0.94 & 1.05 & 1.12 & 0.64 \\
\hline SB3-TTT-700-192HR & 4.47 & 2.99 & 2.25 & 1.39 & SB3-TTT-1100-12HR & 0.97 & 1.06 & 1.20 & 0.64 \\
\hline SB3-TTT-700-785HR & 4.44 & 2.98 & 2.46 & 1.38 & SB3-TTT-1100-48HR & 0.92 & 0.99 & 1.10 & 0.61 \\
\hline SB3-TTT-MIX-CCC & 0.96 & 1.02 & 1.06 & 0.61 & SB3-TTT-MIX-ASR & 0.97 & 1.07 & 1.13 & 0.64 \\
\hline
\end{tabular}


Table 8. PCT Response of the Heat Treated Samples and Crystal Phases Formed

\begin{tabular}{|c|c|c|c|}
\hline Sample ID & Phases & $\begin{array}{c}\text { Vol \% } \\
\text { Crystalline }\end{array}$ & $\begin{array}{c}\text { PCT } \\
\text { Response } \\
\text { NL B (g/L) }\end{array}$ \\
\hline \multirow{3}{*}{ SB3-TTT-600-192HR } & Lithium Silicate $\left(\mathrm{Li}_{2} \mathrm{SiO}_{3}\right)$ & 8.29 & \multirow{3}{*}{3.8} \\
\hline & Aegirine $\left(\mathrm{NaFe}^{3+}\left(\mathrm{SiO}_{3}\right)_{2}\right)$ & 3.06 & \\
\hline & Nepheline $\left(\mathrm{NaAlSiO}_{4}\right)$ & 5.97 & \\
\hline \multirow{3}{*}{ SB3-TTT-600-768HR } & Aegirine $\left(\mathrm{NaFe}^{3+}\left(\mathrm{SiO}_{3}\right)_{2}\right)$ & 32.07 & \multirow{3}{*}{58.5} \\
\hline & Lithium Silicate $\left(\mathrm{Li}_{2} \mathrm{SiO}_{3}\right)$ & 10.86 & \\
\hline & Nepheline $\left(\mathrm{NaAlSiO}_{4}\right)$ & 10.01 & \\
\hline \multirow{3}{*}{ SB3-TTT-700-48HR } & Aegirine $\left(\mathrm{NaFe}^{3+}\left(\mathrm{SiO}_{3}\right)_{2}\right)$ & 2.72 & \multirow{3}{*}{1.5} \\
\hline & Lithium Silicate $\left(\mathrm{Li}_{2} \mathrm{SiO}_{3}\right)$ & 1.47 & \\
\hline & $\begin{array}{l}\text { Krinovite } \\
\left(\mathrm{NaMg}_{2} \mathrm{CrSi}_{3} \mathrm{O}_{10}\right) \\
\end{array}$ & 10.77 & \\
\hline \multirow{2}{*}{ SB3-TTT-700-192HR } & Lithium Silicate $\left(\mathrm{Li}_{2} \mathrm{SiO}_{3}\right)$ & 7.41 & \multirow{2}{*}{3.0} \\
\hline & Aegirine $\left(\mathrm{NaFe}^{3+}\left(\mathrm{SiO}_{3}\right)_{2}\right)$ & 18.66 & \\
\hline \multirow{2}{*}{ SB3-TTT-700-785HR } & Lithium Silicate $\left(\mathrm{Li}_{2} \mathrm{SiO}_{3}\right)$ & 9.67 & \multirow{2}{*}{3.0} \\
\hline & Aegirine $\left(\mathrm{NaFe}^{3+}\left(\mathrm{SiO}_{3}\right)_{2}\right)$ & 19.17 & \\
\hline SB3-TTT-800-48HR & Aegirine $\left(\mathrm{NaFe}^{3+}\left(\mathrm{SiO}_{3}\right)_{2}\right)$ & 0.67 & 1.0 \\
\hline SB3-TTT-800-192HR & Trevorite $\left(\mathrm{NiFe}_{2} \mathrm{O}_{4}\right)$ & 0.99 & 1.1 \\
\hline \multirow{2}{*}{ SB3-TTT-800-785HR } & Trevorite $\left(\mathrm{NiFe}_{2} \mathrm{O}_{4}\right)$ & 2.55 & \multirow{2}{*}{0.9} \\
\hline & Aegirine $\left(\mathrm{NaFe}^{3+}\left(\mathrm{SiO}_{3}\right)_{2}\right)$ & 1.05 & \\
\hline SB3-TTT-900-48HR & Trevorite $\left(\mathrm{NiFe}_{2} \mathrm{O}_{4}\right)$ & 0.60 & 1.0 \\
\hline SB3-TTT-900-192HR & Trevorite $\left(\mathrm{NiFe}_{2} \mathrm{O}_{4}\right)$ & 1.39 & 1.0 \\
\hline SB3-TTT-900-768HR & Trevorite $\left(\mathrm{NiFe}_{2} \mathrm{O}_{4}\right)$ & 0.60 & 1.0 \\
\hline
\end{tabular}




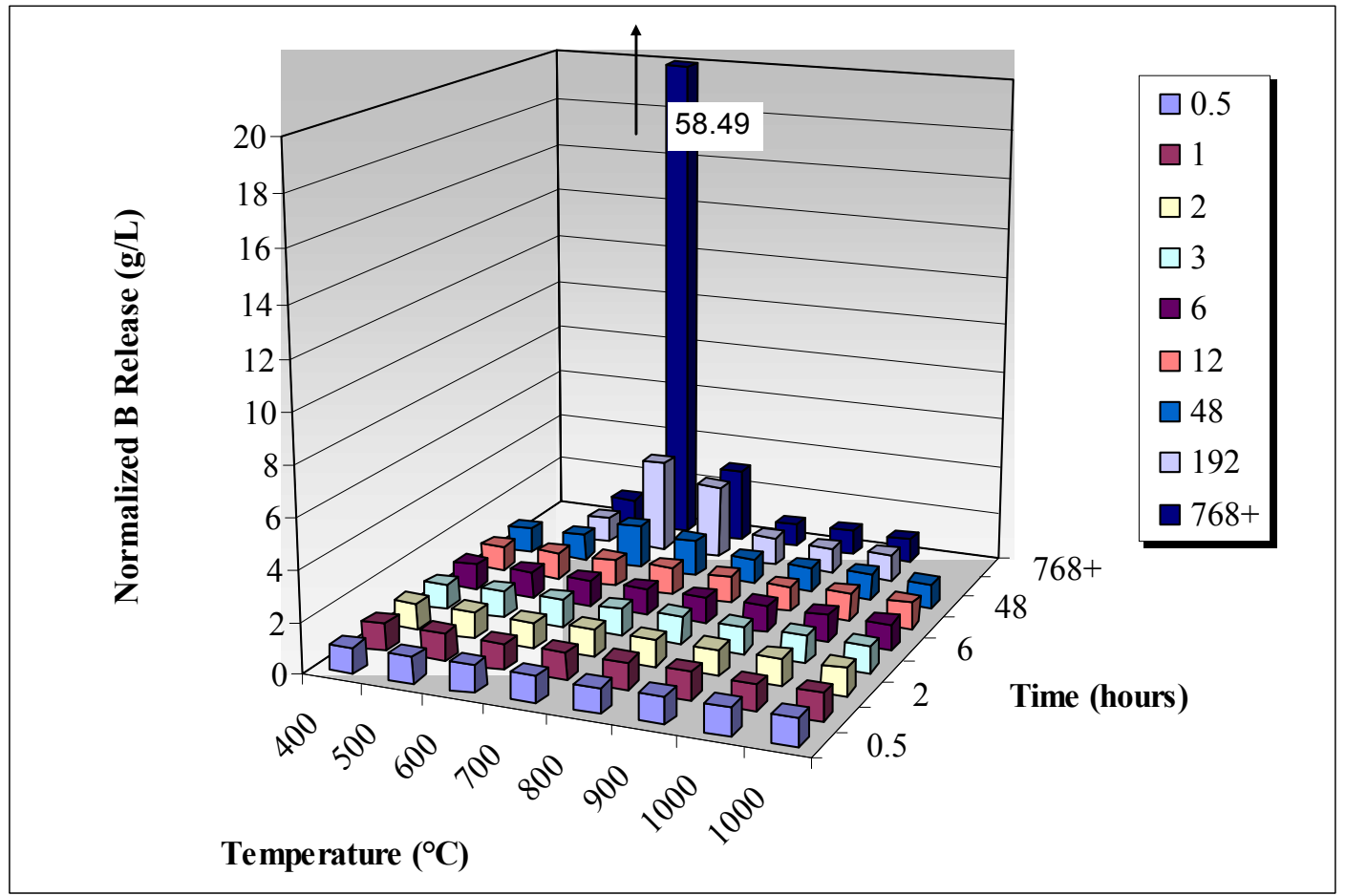

Figure 3. Normalized B Release as a Function of Temperature and Duration of Heat Treatment.

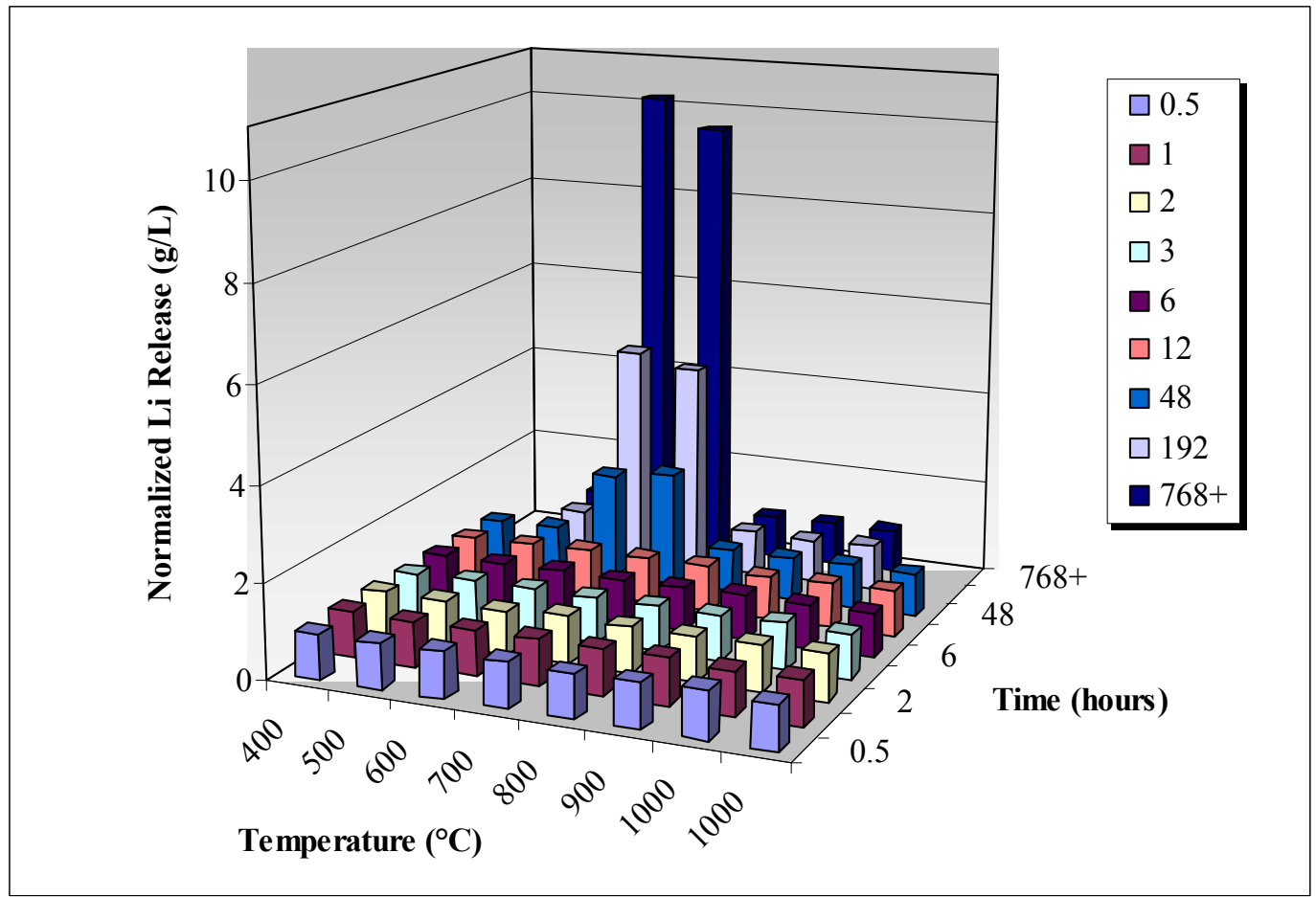

Figure 4. Normalized Li Release as a Function of Temperature and Duration of Heat Treatment 


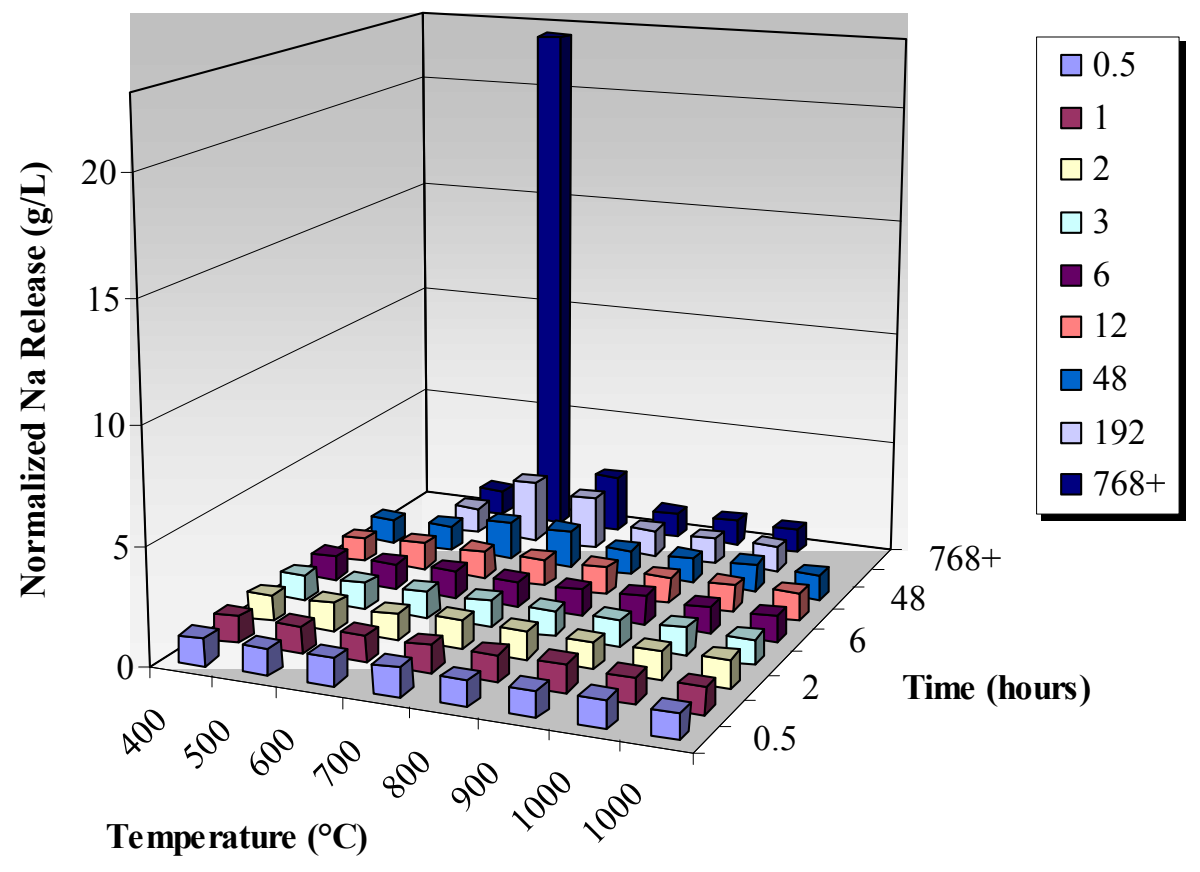

Figure 5. Normalized Na Release as a Function of Temperature and Duration of Heat Treatment.

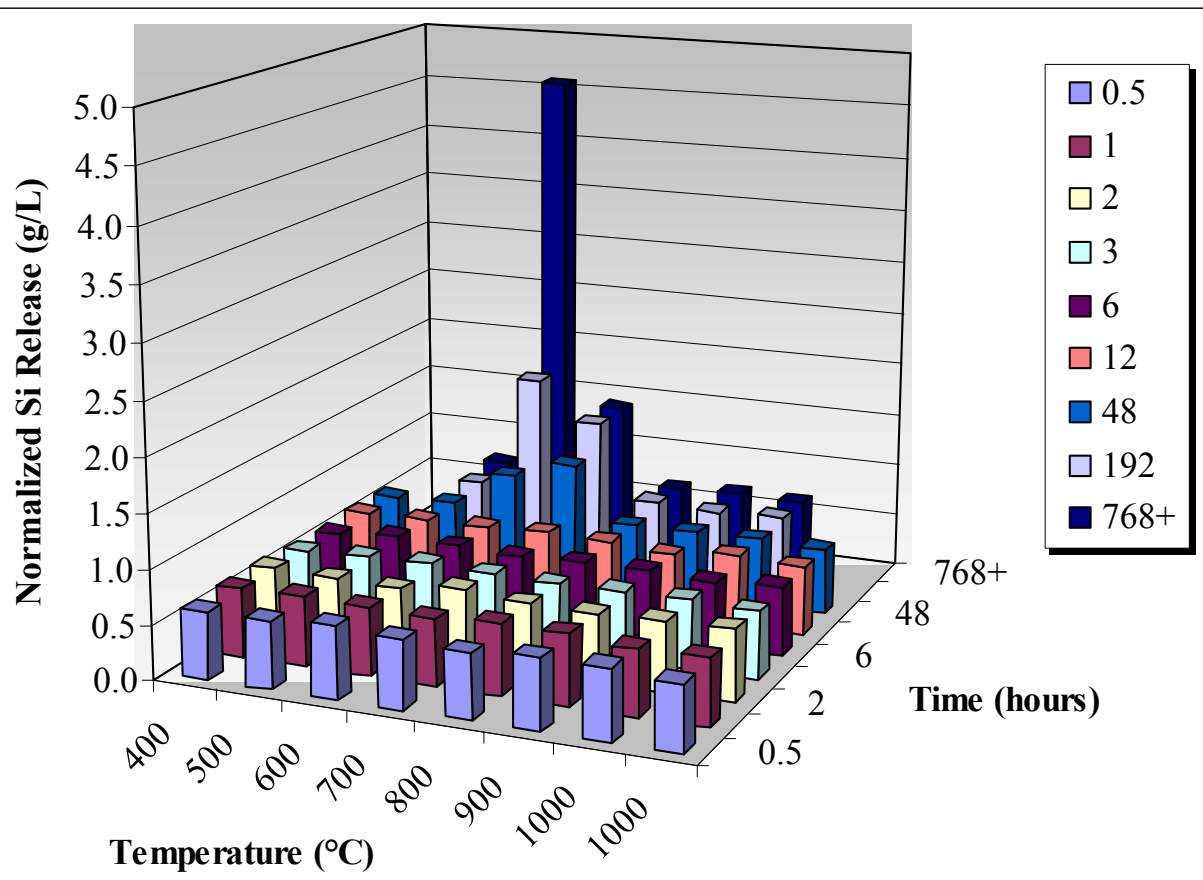

Figure 6. Normalized Si Release as a Function of Temperature and Duration of Heat Treatment. 


\subsection{CONCLUSIONS}

A TTT diagram was completed for a simulated waste glass based on SB3-Frit 418 at a $38 \mathrm{wt} \% \mathrm{WL}$. The diagram was generated using one glass composition heat treated at various temperatures and durations of time. Crystallization only occurred in the temperature region of $600-900{ }^{\circ} \mathrm{C}$ at times greater than 48 hours. For those samples in which crystallization was detected, trevorite and/or aegirine (acmite) were primarily identified by XRD. Lithium metasilicate and nepheline were major phases formed in addition to aegirine at the 600 and $700{ }^{\circ} \mathrm{C}$ temperatures. Crystallization was most prevalent at $600{ }^{\circ} \mathrm{C}$ as approximately $53 \mathrm{vol} \%$ of a sample heat treated for 768 hours at that temperature was crystallized. This particular sample also had the lowest durability (as defined by the PCT) out of all SB3-Frit 418 glasses evaluated in this study.

All glasses except the glass sample heat treated at $600{ }^{\circ} \mathrm{C}$ for 768 hours had a durability better than that of EA (as measured by the PCT). The aforementioned sample had a normalized B release of 58.5 $\mathrm{g} / \mathrm{L}$ as compared to a measured normalized $\mathrm{B}$ release of $19.4 \mathrm{~g} / \mathrm{L}$ for this study and accepted normalized B release of $16.7 \mathrm{~g} / \mathrm{L}$ for EA. ${ }^{21}$ The quenched and $\mathrm{CCC}$ heat treated samples had normalized B releases around $1.0 \mathrm{~g} / \mathrm{L}$. All other samples, except another sample heat treated for 48 hours at $600{ }^{\circ} \mathrm{C}$, had normalized B releases around $1.0 \mathrm{~g} / \mathrm{L}$ as well. The normalized B release for this sample was slightly elevated to $1.7 \mathrm{~g} / \mathrm{L}$. This sample's treatment conditions are located on the edge of the estimated nepheline, lithium silicate, aegirine, krinovite and albite phase region and most likely had traces of the durability reducing nepheline phase present which was below the detection limit of the X-ray diffractometer $(<0.5 \mathrm{vol} \%)$. Those samples which had normalized releases for $\mathrm{Li}, \mathrm{B}, \mathrm{Na}$, and $\mathrm{Si}$ greater than the majority of the samples, which remained amorphous, had detectable amounts of lithium silicate and nepheline present. This is expected as these silicate and aluminosilicate crystalline phases reduce the amount of glass forming components in the residual glass as the volume fraction of these phases increase.

The onset $\mathrm{T}_{\mathrm{g}}$ of this particular glass was measured at $443{ }^{\circ} \mathrm{C} \pm 3$, therefore this glass will never exhibit a change in morphology below that temperature, no matter the duration. Of the matrix of times and temperatures tested, crystallization did not occur until far beyond the temperatures and times represented by the CCC curve. The $\mathrm{T}_{\mathrm{g}}$ of this glass fell within the region of measured temperatures of the WCP glasses and also satisfied the requirement of having a $\mathrm{T}_{\mathrm{g}}$ above $400{ }^{\circ} \mathrm{C}$. ${ }^{3}$ Phases and regions of maximum crystallization were within the same crystalline families if not the same as those previously observed. ${ }^{2}$ This supports that even under extremely different processing strategies, the waste form still behaved similarly with respect to phase transformation when treated under abnormal temperature conditions. The conditions imposed on the glass during this study are highly unlikely to occur to any waste glass currently being stored at DWPF. 


\subsection{RECOMMENDATIONS}

In order to continue with creating TTT diagrams for predicted waste types, a strategy has been developed that would require completing more TTT diagrams for two averaged, future, predicted waste types. Since the results of the current study showed little change in the types of crystalline phases formed after heat treatment as compared to the TTT diagrams for the WCP glasses, it is unlikely that extreme differences will occur in the TTT diagram for future glasses. By creating diagrams for the resulting glass compositions of encompassing waste types, it will give likely insight to the crystallization regions possible for those averages. It will also supply experimental data to establish any possible difference in the phases formed or different temperatures at which crystallization will occur. If the results are not significantly different from the WCP glasses or the current glass, it would negate the need to create TTT diagrams for each sludge batch or glass composition produced at the DWPF.

As discussed in the report, "Initial MAR Assessments to Access the Impact of Al-Dissolution on DWPF Operating Windows" (WSRC-STI-2007-00688) ${ }^{25}$, the majority of future waste compositions could be grouped into two flowsheet scenarios, with and without Al-dissolution. Compositions Cluster 2 and Cluster 4 represent these waste projections. MAR assessments were completed on the two clusters and possible frits and windows of operation were selected for each projected waste type. It is recommended that a TTT diagram be completed for the following:

- Cluster 2 combined with Frit-510 at a $34 \mathrm{wt} \% \mathrm{WL}$

- Cluster 4 combined with Frit-418 at a 38 wt \% WL

Using the experimental parameters and results from the current study as a guide, certain temperatures and durations of heat treatment could be eliminated in the next phase of experimental testing. This would lead to fewer samples that would be needed to be characterized. Those temperatures for very short durations of time and heat treated at temperatures of $1100{ }^{\circ} \mathrm{C}$ and $400{ }^{\circ} \mathrm{C}$ have had no evidence of crystallization and could be eliminated after verifying the glass transition temperature. If, during future testing and generation of the next stage of TTT diagrams, it is felt that a significant change in the projected waste composition has occurred that could potentially impact crystallization, more TTT diagrams will be generated. This effort would start with select heat treatment points to determine the potential phase changes. 


\section{REFERENCES}

1. "Waste Acceptance Product Specification for Vitrified High-Level-Waste Forms," Office of Environmental Management USDOE Document, DOE/EM-0093, Rev. 2, 1996.

2. C.A. Cicero, S.L. Marra, and M.K. Andrews, "Phase Stability Determinations of DWPF Waste Glasses (U)," Westinghouse Savannah River Company, Aiken, SC, WSRC-TR-9300227, Revision 0, May, 1993.

3. S.L. Marra and M.J. Plodinec, "DWPF Waste Form Compliance Plan," Savannah River Site, Aiken, SC, USDOE Document WSRC-IM-91-116-0 Rev. 8, March, 2006.

4. T.H. Lorier, T.B. Edwards, I.A. Reamer, D.R. Best, and D.K. Peeler, "SB3 Phase 2 Variability Study: The Impact of REDOX on Durability for the Frit 418-SB2/3 System," Savannah River National Laboratory, Aiken, SC, WSRC-TR-2003-00539, 2003.

5. B.H. Culbertson, "Technical Task Request: Develop Time-Temperature-Transformation (TTT) Diagrams for New Composition Ranges," Savannah River Site, Aiken, SC, HLWDWPF-TTR-2006-0015 Rev.1, 2007.

6. K.M. Fox, "Task Technical \& QA Plan: Develop Time-Temperature-Transformation (TTT) Diagrams for New Composition Ranges," Washington Savannah River Company, Aiken, SC, WSRC-STI-2006-00004, Rev. 1, 2007.

7. C.M. Jantzen, " Research Notebook DPSTN-4155 (E30653)," Savannah River National Laboratory, Aiken, SC, 1984.

8. C.M. Jantzen, " Research Notebook DPSTN-4193 (E35142)," Savannah River National Laboratory, Aiken, SC, 1984.

9. D.K. Peeler and T.B. Edwards, "Frit 202-SB3 Sulfate Solubility Assessment," Savannah River National Laboratory, Aiken, SC, Inter-Office Memorandum, SRT-GPD-2004-00069, 2004.

10. D.F. Bickford and C.M. Jantzen, "Devitrification of Defense Nuclear Waste Glasses: Role of Melt Insolubles," J. Non-Cryst. Solids, 84 [1-3] 299-307 (1986).

11. "Glass Melting," Savannah River National Laboratory, Aiken, SC, SRTC Procedure Manual, L29, ITS-0003, 2002.

12. "Glass Batching," Savannah River National Laboratory, Aiken, SC, SRTC Procedure Manual, L29, ITS-0001, 2002.

13. "TTT Diagrams," Savannah River National Laboratory, Aiken, SC, Laboratory Notebook, WSRC-NB-2006-00074, 2006.

14. T.B. Edwards, "An Analytical Plan for Measuring the Chemical Composition of Glass That Is to Be Used for a SB3 TTT Study," Savannah River National Laboratory, Aiken, SC, InterOffice Memorandum SRNL-SCS-2007-00004, 2007. 
15. C.M. Jantzen, M.A. Pickett, K.G. Brown, T.B. Edwards, and D.C. Beam, "Process/Product Models for the Defense Waste Processing Facility (DWPF): Part I. Predicting Glass Durability from Composition Using a Thermodynamic Hydration Energy Reaction Model (THERMO)," Savannah River Technology Center, Aiken,SC, WSRC-TR-93-0672, 1993.

16. T.B. Edwards, "A Statistical Review of the Chemical Compositions of the Batched Glass for the SB3 TTT Study," Savannah River National Laboratory, Aiken, SC, Inter-Office Memorandum SRNL-SCS-2007-00027, 2007.

17. "Standard Test Method for Assignment of the Glass Transition Temperatures by Differential Scanning Calorimetry," American Society for Testing and Materials (ASTM), West Conshohocken, PA, ASTM Standard E 1356, 2003.

18. S.L. Marra and C.M. Jantzen, "Characterization of Projected DWPF Glass Heat Treated to Simulate Canister Centerline Cooling," Westinghouse Savannah River Company, Aiken, SC, WSRC-TR-92-142, Rev. 1, 1993.

19. "Glass Density Using the Mettler AT400 (or Equivalent Balance)," Savannah River National Laboratory, Aiken, SC, SRTC Procedure Manual, L29, ITS-0057, 2006.

20. "Standard Test Methods for Determining Chemical Durability of Nuclear, Hazardous, and Mixed Waste Glasses and Multiphase Glass Ceramics: The Product Consistency Test (PCT)," American Society for Testing and Materials (ASTM), West Conshohocken, PA, ASTM Standard C 1285-02, 2002.

21. C.M. Jantzen, N.E. Bibler, D.C. Beam, C.L. Crawford, and M.A. Pickett, "Characterization of the Defense Waste Processing Facility (DWPF) Environmental Assessment (EA) Glass Standard Reference Material," Savannah River Site, Aiken, SC, WSRC-TR-92-346, Rev. 1, 1994.

22. T.B. Edwards, "An Analytical Plan for Measuring the PCT Solutions for the Glasses Subjected to the First Set of Heat Treatments for the SB3 TTT Study," Savannah River National Laboratory, Aiken, SC, Inter-Office Memorandum SRNL-SCS-2007-00038, 2007.

23. T.B. Edwards, "An Analytical Plan for Measuring the PCT Solutions for the Glasses Subjected to the Second Set of Heat Treatments for the SB3 TTT Study," Savannah River National Laboratory, Aiken, Sc, Inter-Office Memorandum SRNL-SCS-2007-00063, 2007.

24. B.H. Culbertson, S.L. Marra, M.K. Andrews, C.A. Cicero, B.J. Hardy, and M.J. Plodinec, "Phase Stability and Control of the Temperature of the DWPF Product," Savannah River National Laboratory, Aiken, SC, WSRC-IM-91-116-7, Rev. 1, 2006.

25. J.D. Newell, T.B. Edwards, and D.K. Peeler, "Initial MAR Assessments to Access the Impact of Al-Dissolution on DWPF Operating Windows," Savannah River National Laboratory, Aiken, SC, WSRC-STI-2007-00688, 2007. 


\section{APPENDIX A.}

Table A1. Waste Form Compositions of Various Glasses Used to Generate TTT Diagrams ${ }^{2,3,7,8}$

\begin{tabular}{|c|c|c|c|c|c|c|c|c|c|c|c|c|c|c|}
\hline $\begin{array}{c}\text { Oxide } \\
\text { (wt \%) }\end{array}$ & $\begin{array}{c}\text { SB3- } \\
\text { Frit } \\
418 \\
\end{array}$ & Blend & HM & Purex & $\begin{array}{c}\text { Batch } \\
\# 1\end{array}$ & $\begin{array}{c}\text { Batch } \\
\# 2\end{array}$ & $\begin{array}{c}\text { Batch } \\
\# 3\end{array}$ & $\begin{array}{c}\text { Batch } \\
\# 4\end{array}$ & $\begin{array}{c}165 \\
\text { High } \\
\text { Al }\end{array}$ & $\begin{array}{c}165 \mathrm{Av} \\
\text { (TDS) }\end{array}$ & $\begin{array}{c}165 \\
\text { High } \\
\text { Fe }\end{array}$ & $\begin{array}{c}131 \\
\text { High } \\
\text { Al }\end{array}$ & $\begin{array}{l}131 \mathrm{Av} \\
\text { (TDS) }\end{array}$ & $\begin{array}{c}131 \\
\text { High } \\
\text { Fe } \\
\end{array}$ \\
\hline $\mathrm{Al}_{2} \mathrm{O}_{3}$ & 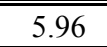 & 4.16 & 7.15 & 2.99 & 4.88 & 4.63 & 3.44 & 3.43 & 10.15 & 25.54 & 2.59 & 10.51 & 7.81 & 3.04 \\
\hline $\mathrm{BaO}$ & 0.06 & 0.18 & 0.11 & 0.20 & 0.15 & 0.16 & 0.18 & 0.25 & 0.16 & 0.33 & 0.10 & 0.04 & 0.07 & 0.04 \\
\hline $\mathrm{CaO}$ & 1.13 & 1.03 & 1.01 & 1.09 & 1.22 & 1.08 & 0.99 & 0.84 & 1.42 & 1.67 & 1.14 & 1.49 & 1.56 & 1.63 \\
\hline $\mathrm{Ce}_{2} \mathrm{O}_{3}$ & 0.09 & - & - & - & - & - & - & - & - & - & - & - & - & - \\
\hline $\mathrm{Cr}_{2} \mathrm{O}_{3}$ & 0.09 & 0.13 & 0.09 & 0.15 & 0.11 & 0.13 & 0.14 & 0.14 & 0.19 & 0.19 & 0.14 & 0.17 & 0.20 & 0.19 \\
\hline $\mathrm{Cs}_{2} \mathrm{O}$ & - & 0.08 & 0.06 & 0.06 & 0.06 & 0.02 & 0.06 & 0.09 & 0.00 & 0.03 & 0.03 & 0.03 & 0.03 & 0.03 \\
\hline $\mathrm{CuO}$ & 0.04 & 0.44 & 0.25 & 0.42 & 0.40 & 0.42 & 0.40 & 0.45 & 0.06 & 0.00 & 0.06 & 0.06 & 0.06 & 0.08 \\
\hline $\mathrm{Fe}_{2} \mathrm{O}_{3}$ & 12.75 & 10.91 & 7.78 & 13.25 & 12.84 & 11.12 & 11.71 & 11.71 & 7.53 & 12.14 & 15.52 & 11.36 & 11.44 & 13.52 \\
\hline $\mathrm{K}_{2} \mathrm{O}$ & 0.08 & 3.67 & 2.21 & 3.41 & 3.33 & 3.38 & 3.40 & 3.86 & - & - & - & - & - & - \\
\hline $\mathrm{La}_{2} \mathrm{O}_{3}$ & 0.04 & - & - & - & - & - & - & - & 0.05 & 0.11 & 0.07 & 0.14 & 0.16 & 0.21 \\
\hline $\mathrm{Li}_{2} \mathrm{O}$ & 5.16 & 4.44 & 4.62 & 3.22 & 4.43 & 4.50 & 4.51 & 4.29 & 3.99 & 3.96 & 4.51 & 3.09 & 3.24 & 3.53 \\
\hline $\mathrm{MgO}$ & 1.39 & 1.41 & 1.49 & 1.41 & 1.42 & 1.42 & 1.42 & 1.43 & 0.87 & 0.89 & 0.95 & 1.40 & 1.71 & 1.59 \\
\hline $\mathrm{MnO}$ & 2.59 & 1.67 & 1.75 & 1.69 & 1.72 & 1.41 & 1.53 & 2.54 & 1.45 & 2.08 & 2.71 & 2.39 & 1.96 & 2.59 \\
\hline $\mathrm{Na}_{2} \mathrm{O}$ & 13.88 & 9.13 & 8.56 & 12.62 & 9.00 & 9.21 & 9.01 & 9.16 & 8.48 & 8.26 & 9.88 & 8.90 & 10.89 & 12.29 \\
\hline $\mathrm{Nd}_{2} \mathrm{O}_{3}$ & - & 0.22 & 0.55 & 0.06 & 0.15 & 0.26 & 0.17 & 0.39 & - & - & - & - & - & - \\
\hline $\mathrm{NiO}$ & 0.69 & 0.89 & 0.41 & 1.19 & 0.75 & 0.90 & 1.05 & 1.06 & 0.97 & 1.15 & 1.94 & 0.94 & 1.26 & 1.03 \\
\hline $\mathrm{P}_{2} \mathrm{O}_{5}$ & - & - & - & - & - & - & - & - & 0.14 & 0.16 & 0.09 & 0.12 & 0.14 & 0.13 \\
\hline $\mathrm{PbO}$ & 0.06 & - & - & - & - & - & - & - & 0.26 & 0.35 & 0.51 & 0.42 & 0.43 & 0.46 \\
\hline $\mathrm{RuO}_{2}$ & 0.02 & 0.03 & 0.04 & 0.01 & 0.02 & 0.04 & 0.03 & 0.05 & 0.07 & 0.10 & 0.05 & 0.06 & 0.05 & 0.06 \\
\hline $\mathrm{SiO}_{2}$ & 50.20 & 51.90 & 55.80 & 46.50 & 50.20 & 52.10 & 52.60 & 50.10 & 52.52 & 52.13 & 50.26 & 43.25 & 46.00 & 45.08 \\
\hline $\mathrm{SO}_{4}$ & 0.43 & - & - & - & - & - & - & - & - & - & - & - & - & - \\
\hline $\mathrm{SrO}$ & - & - & - & - & - & - & - & - & 0.05 & 0.05 & 0.08 & 0.05 & 0.06 & 0.05 \\
\hline $\mathrm{ThO}_{2}{ }^{*}$ & - & - & - & - & - & - & - & - & 1.07 & 0.30 & 0.03 & 1.07 & 0.30 & 0.03 \\
\hline $\mathrm{TiO}_{2}$ & 0.01 & 0.89 & 0.56 & 0.68 & 0.68 & 0.69 & 0.68 & 1.03 & 0.07 & 0.07 & 0.16 & 0.72 & 0.75 & 0.74 \\
\hline $\mathrm{U}_{3} \mathrm{O}_{8}$ & & - & - & - & - & - & - & - & 0.91 & 1.13 & 1.91 & 2.16 & 1.93 & 2.11 \\
\hline $\mathrm{ZnO}$ & 0.06 & - & - & - & - & - & - & - & 0.04 & 0.05 & 0.08 & 0.09 & 0.05 & 0.09 \\
\hline $\mathrm{ZrO}_{2}$ & 0.11 & 0.14 & 0.33 & 0.05 & 0.10 & 0.17 & 0.12 & 0.22 & 1.05 & 1.09 & 0.77 & 0.47 & 0.47 & 0.50 \\
\hline SUM & 100.00 & 99.52 & 100.02 & 999.41 & 99.35 & 99.69 & 99.25 & 999.38 & 100.00 & 100.00 & 100.01 & 100.01 & 100.01 & 100.01 \\
\hline
\end{tabular}

* $\mathrm{ThO}_{2}$ was calculated from batch compositions. 
Table A2. Frit Compositions Used to Calculate the Waste Glass Compositions in Table A1.

\begin{tabular}{|c|c|c||}
\hline $\begin{array}{c}\text { Oxide } \\
\text { (wt \%) }\end{array}$ & Frit 165 & Frit 131 \\
\hline $\mathrm{B}_{2} \mathrm{O}_{3}$ & 10.0 & 14.7 \\
\hline $\mathrm{La}_{2} \mathrm{O}_{3}$ & -- & 0.5 \\
\hline $\mathrm{Li}_{2} \mathrm{O}$ & 7.0 & 5.7 \\
\hline $\mathrm{MgO}$ & 1.0 & 2.0 \\
\hline $\mathrm{Na}_{2} \mathrm{O}$ & 13.0 & 17.7 \\
\hline $\mathrm{SiO}_{2}$ & 68.0 & 57.9 \\
\hline $\mathrm{TiO}_{2}$ & -- & 1.0 \\
\hline $\mathrm{ZrO}_{2}$ & 1.0 & 0.5 \\
\hline
\end{tabular}




\section{Distribution:}

J. C. Griffin, 773-A

S. L. Marra, 773-A

A. B. Barnes, 999-W

D. A. Crowley, 773-43A

S. D. Fink, 773-A

C. W. Gardner, 773-A

B. J. Giddings, 786-5A

C. C. Herman, 999-W

F. M. Pennebaker, 773-42A

J. E. Occhipinti, 704-S

D. C. Sherburne, 704-S

R. T. McNew, 704-27S

J. F. Iaukea, 704-30S

J. W. Ray, 704-S

H. B. Shah, 766-H

J. M. Gillam, 766-H

B. A. Hamm, 766-H

D. D. Larsen, 766-H

C. J. Bannochie, 773-42A

D. J. McCabe, 773-42A

D. K. Peeler, 999-W

M. E. Stone, 999-W

J. P. Vaughan, 773-41A

R.L. Hinds 704-S

A. J. Cross, 704-71S

T. L. Fellinger, 704-26S

C. M. Jantzen, 773-A

K. M. Fox, 999-W

T. B. Edwards, 999-W

F. C. Raszewski, 999-W 